\section{Kidney \\ Blood Pressure \\ Research}

\title{
Renal and Cardiac Effects of DPP-4 Inhibitors - from Preclinical Development to Clinical Research
}

\author{
Berthold Hocher ${ }^{\mathrm{a}, \mathrm{b}}$ Christoph Reichetzeder ${ }^{\mathrm{a}, \mathrm{b}}$ Markus L. Alter ${ }^{\mathrm{a}, \mathrm{b}, \mathrm{c}}$ \\ aInstitute of Nutritional Science, University of Potsdam, Potsdam, Germany, ${ }^{b} \mathrm{Center}$ for Cardiovascular \\ Research, Charité, Berlin, Germany, 'Department of Nephrology, Campus Benjamin Franklin, Charité, \\ Berlin, Germany
}

\section{Key Words}

DDP-4 inhibition • Diabetes $\cdot$ GLP-1 1 Cardiovascular effects $•$ Myocardial infarction • Kidney • Diabetic nephropathy $\cdot$ Acute renal failure

\begin{abstract}
Inhibitors of type 4 dipeptidyl peptidase (DDP-4) were developed and approved for the oral treatment of type 2 diabetes. Its mode of action is to inhibit the degradation of incretins, such as type 1 glucagon like peptide (GLP-1), and GIP. GLP-1 stimulates glucose-dependent insulin secretion from pancreatic beta-cells and suppresses glucagon release from alpha-cells, thereby improving glucose control. Besides its action on the pancreas type 1 glucagon like peptide has direct effects on the heart, vessels and kidney mainly via the type 1 glucagon like peptide receptor (GLP-1R). Moreover, there are substrates of DPP-4 beyond incretins that have proven renal and cardiovascular effects such as BNP/ANP, NPY, PYY or SDF-1 alpha. Preclinical evidence suggests that DPP-4 inhibitors may be effective in acute and chronic renal failure as well as in cardiac diseases like myocardial infarction and heart failure. Interestingly, large cardiovascular meta-analyses of combined Phase II/III clinical trials with DPP-4 inhibitors point all in the same direction: a potential reduction of cardiovascular events in patients treated with these agents. A pooled analysis of pivotal Phase III, placebo-controlled, registration studies of linagliptin further showed a significant reduction of urinary albumin excretion after 24 weeks of treatment. The observation suggests direct renoprotective effects of DPP-4 inhibition that may go beyond its glucose-lowering potential. Type 4 dipeptidyl peptidase inhibitors have been shown to be very well tolerated in general, but for those excreted via the kidney dose adjustments according to renal function are needed to avoid side effects. In conclusion, the direct cardiac and renal effects seen in preclinical studies as well as meta-analysis of clinical trials may offer additional potentials - beyond improvement of glycemic control - for this newer class of drugs, such as acute kidney failure, chronic kidney failure as well as acute myocardial infarction and heart failure.
\end{abstract}




\section{Kidney Blood Pressure Research}

Hocher/Reichetzeder/Alter: Renal and Cardiac Effects of DPP4 Inhibitors.

\section{Introduction}

The growing pandemic that is type 2 diabetes mellitus (T2DM) and the burden it is expected to place on shrinking healthcare resources represents a potential global public health crisis. In the United States alone, 9.6\% of persons aged 20 years and older have diabetes and it has been estimated that almost $20 \%$ of the population are in a pre-diabetic state. Extrapolation of available data predicts that by 2025 this number will have increased by $42 \%$ in developed countries and, perhaps more troublingly, by $170 \%$ in developing nations. Type 2 diabetes is expected to account for about $95 \%$ of the total diabetic burden [1-3].

The secondary complications associated with diabetes are frequent, severe, progressive and costly [1-3]. Representing a significant burden of morbidity and mortality they include diabetic nephropathy, coronary heart disease, stroke, peripheral arterial disease, neuropathy, retinopathy as well as heart failure and periodontal disease. Diabetic complications are responsible for a reduction in mean life expectancy of 12 years in men and 19 years in women. The end organ morbidities associated with diabetes each places a heavy tax on healthcare resources and diminish patient quality of life with diabetic nephropathy being perhaps the complication with greatest socioeconomic impact [1-3].

Despite providing effective reductions in levels of type $1 \mathrm{~A}$ glycated hemoglobin (HbA1c) current therapeutic options for the treatment of T2DM appear to offer little benefit in terms of protection from end organ damage. Some recent analyses of carefully devised and monitored studies recording data on cardiovascular events have even questioned the cardiovascular safety of established antidiabetic drugs [4-7]. The cardiovascular safety of more recently approved antidiabetic agents which offer new approaches to glucose management and potentially more comprehensive alternatives to managing hyperglycemia has also been somewhat disappointing [8-10].

Although the safety profile of the recently introduced type 4 dipeptidyl peptidase (DPP-4) inhibitor class of antidiabetic drugs has yet to be formally assessed, there is anticipation that they will offer benefits over existing therapies. For example, DPP-4 inhibitors are not expected to display the water and salt retention profile seen with peroxisome proliferator-activated receptor (PPAR) alpha/gamma agonists. The antidiabetic action of DPP-4 inhibitors is based on inhibition of type 1 glucagon-like peptide (GLP-1) (Fig. 1), which has beneficial renal and cardiac actions beyond those on glucose homeostasis. Moreover, there are other peptide hormones with direct cardiorenal effects that are themselves substrates of DPP-4. The long-term impact of augmentation of GLP-1 levels and those of other peptide hormones consequent to DPP-4 inhibition has still to be established in a clinical setting. In reviewing here the data from preclinical and clinical studies we speculate on the potential for DPP-4 inhibitors to provide cardiorenal benefits beyond those directly associated with glucose lowering.

\section{Clinical Pharmacology of DPP-4 inhibitors}

Approved for the treatment of T2DM either as monotherapy, add-on or initial combinatorial therapy with other glucose-lowering agents, all currently marketed DPP-4 inhibitors are oral formulations with a high degree of selectivity for their target enzyme (Table 1). The first DPP-4 inhibitor to become available for clinical use was sitagliptin in 2006 and it is currently available as monotherapy or in a fixed-dose combination with other antidiabetic agents, for example metformin. It is a competitive and fully reversible DPP-4 inhibitor with a half maximal inhibitory concentration $\left(\mathrm{IC}_{50}\right)$ of $18 \mathrm{nM}$ [11]. The high selectivity ensures a targeted action on DPP-4 and prevents unwanted secondary effects or potential toxicities resulting from cross-inhibition of other DPP enzymes such as DPP-8 or DPP-9 [12]. At dosages of $50 \mathrm{mg}$ once daily (od) in healthy subjects sitagliptin reduces DPP-4 activity by approximately $80 \%$ at 12 hours and administration of $100 \mathrm{mg}$ od maintains inhibition at similar levels for 24 hours [13]. Moreover, sitagliptin is well-tolerated with these levels 


\section{Kidney Blood Pressure Research}

Kidney Blood Press Res 2012;36:65-84

DOI: $10.1159 / 000339028$

Published online: August 27, 2012

(c) 2012 S. Karger AG, Basel

www.karger.com/kbr

Table 1: Pharmacokinetics of DPP-4 inhibitors [13, 15, 20, 22, 23, 26, 28, 30, 33, 34, 36-39]

\begin{tabular}{|c|c|c|c|c|c|c|}
\hline Drug & Sitagliptin & Vildagliptin & Linagliptin & Saxagliptin & $\begin{array}{l}\text { 5-hydroxy } \\
\text { Saxagliptin } \\
\text { (active } \\
\text { metabolite) }\end{array}$ & Alogliptin \\
\hline Blockade & $\begin{array}{c}\text { Competitive } \\
{[34]}\end{array}$ & $\begin{array}{c}\text { substrate blocker } \\
{[20]}\end{array}$ & Competitive [26] & \multicolumn{2}{|c|}{ Competitive [33] } & Competitive [38] \\
\hline $\begin{array}{c}\text { Oral } \\
\text { administration }\end{array}$ & $1 \times 100 \mathrm{mg} /$ day [36] & $2 \times 50 \mathrm{mg} /$ day [22] & $1 \times 5$ mg/day [28] & \multicolumn{2}{|l|}{$1 \times 5 \mathrm{mg} /$ day } & $\begin{array}{c}1 \times 12.5-25 \mathrm{mg} / \text { day } \\
{[39]}\end{array}$ \\
\hline Metabolization & low & $\begin{array}{c}\text { extensively, } \\
\text { probably liver } \\
{[22,23]}\end{array}$ & Low $[30]$ & \multicolumn{2}{|c|}{$\begin{array}{l}\text { yes, saxagliptin to 5-hydroxy } \\
\text { saxagliptin; P450 in liver } \\
\text { involved }[36,37]\end{array}$} & Low [39] \\
\hline Excretion & $\begin{array}{l}80 \% \text { unchanged via } \\
\text { urine }[13]\end{array}$ & $\begin{array}{c}\text { via urine, } 21 \% \\
\text { unchanged [22] }\end{array}$ & $\begin{array}{c}84 \% \text { unchanged via } \\
\text { feces, }<6 \% \text { urine } \\
{[28,30]}\end{array}$ & $\begin{array}{c}12-29 \% \text { via } \\
\text { urine [36] }\end{array}$ & $\begin{array}{c}21-51 \% \text { via } \\
\text { urine [36] }\end{array}$ & $\begin{array}{c}60-71 \% \text { via urine, } \\
\text { unchanged [39] }\end{array}$ \\
\hline $\begin{array}{c}\text { Renal } \\
\text { Insufficiency }\end{array}$ & $\begin{array}{c}\text { dose adjustment } \\
{[15]}\end{array}$ & dose adjustment & no dose adjustment & \multicolumn{2}{|c|}{ dose adjustment [37] } & $\begin{array}{l}\text { probably dose } \\
\text { adjustment } \\
\text { recommended }\end{array}$ \\
\hline $\begin{array}{c}\text { Hepatic } \\
\text { Insufficiency }\end{array}$ & no dose adjustment & not recommended & no dose adjustment & \multicolumn{2}{|c|}{$\begin{array}{l}\text { dose adjustment in co- } \\
\text { administration with CYP- } \\
\text { enhancers/ suppressors; no } \\
\text { adjustment in } \mathrm{HI} \text { [37] }\end{array}$} & no dose adjustment \\
\hline
\end{tabular}

Fig. 1. Substrates of DDP-4 with potential cardio-renal effects. DPP-4, type 4 dipeptidyl peptidase; GLP-1, type 1 glucagon like peptide; GIP, gastric inhibitory polypeptide; BNP, brain natriuretic peptide; SDF-1, type 1 stromal derived factor; NPY, neuropeptide; PYY, peptide YY; His, histidine; Pro, proline; Tyr, tyrosine; Ala, alanine; Ser, serine.

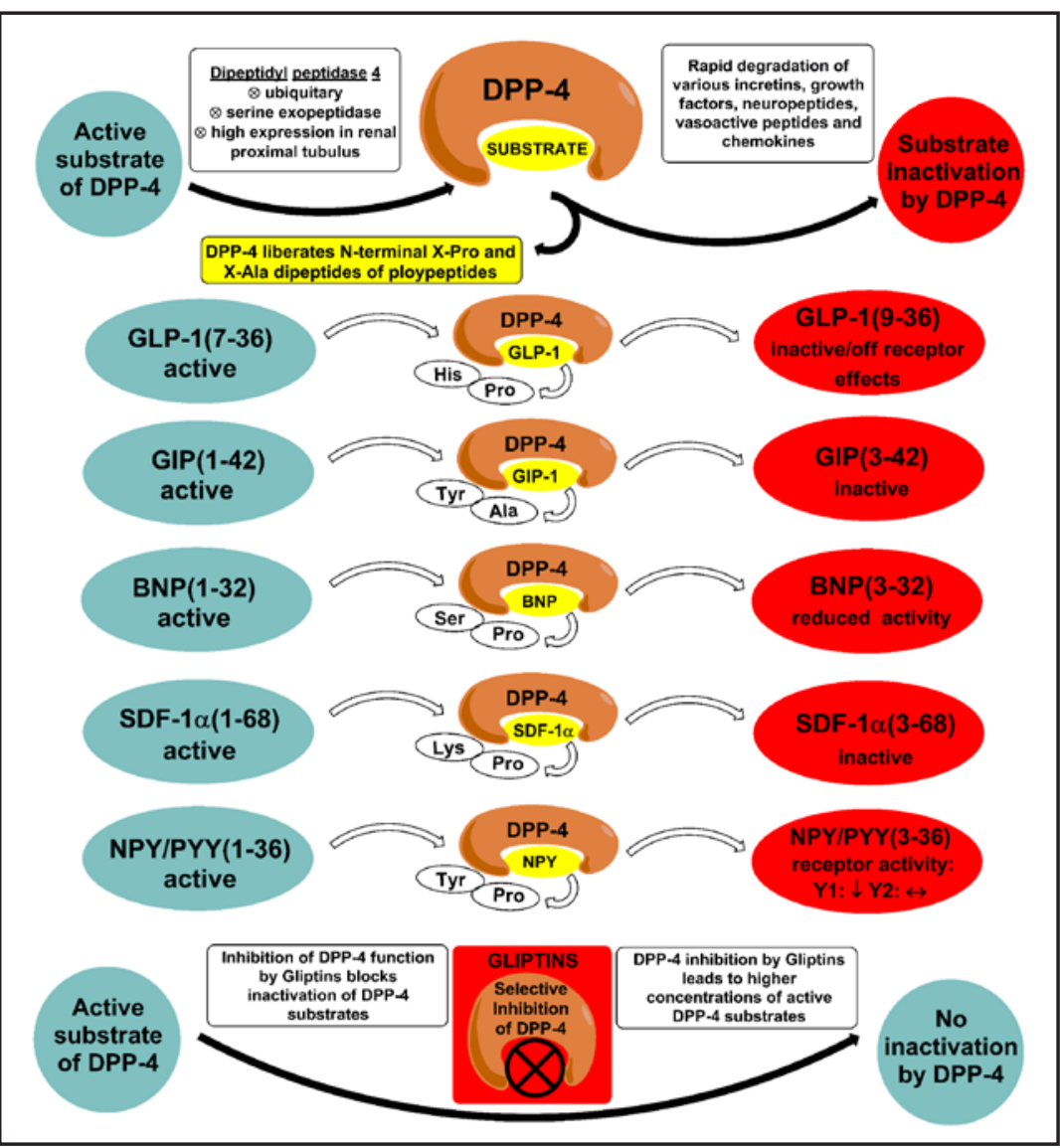

of inhibition being achieved in the absence of any overt increase in adverse event reporting or episodes of hypoglycemia, even at doses six times higher than the recommended $100 \mathrm{mg}$ oral dose [13]. In patients with T2DM, a dose of $100 \mathrm{mg}$ od achieved a 24-hour mean DPP-4 inhibition of over $80 \%$, which resulted in a two-fold increase in active GLP-1 and gastric inhibitory polypeptide (GIP) levels, leading to near-maximal decrease of plasma glucose following an oral glucose tolerance test [14].

Sitagliptin has a high bioavailability, with approximately $80 \%$ of parent drug excreted unchanged in the urine. Renal clearance rates (ca. $388 \mathrm{ml} / \mathrm{min}$ ) are also independent of the 


\section{Kidney Blood Pressure Research}

Kidney Blood Press Res 2012;36:65-84

\begin{tabular}{l|l}
\hline DOI: $10.1159 / 000339028$ & C) 2012 S. Karger AG, Basel \\
Published online: August 27, 2012 & www.karger.com/kbr
\end{tabular}

Hocher/Reichetzeder/Alter: Renal and Cardiac Effects of DPP4 Inhibitors.

administered dose [13], which is a consequence of ready glomerular filtration and active secretion of sitagliptin into the lumen of the nephron facilitated by the human organic anion transporter (hOAT3) [15]. Investigation into the effect of renal insufficiency on the pharmacokinetic profile of sitagliptin resulted in the recommendation that the dose beadjusted in patients with moderate or severe renal insufficiency or end stage renal disease (ESRD). No dose adjustment is needed for patients with mild renal insufficiency with a creatinine clearance above $50 \mathrm{ml} / \mathrm{min}$ (i.e., $100 \mathrm{mg}$ od). However, half the dose is recommended for patients with moderate renal insufficiency (creatinine clearance of $30-50 \mathrm{ml} / \mathrm{min}$; i.e., $50 \mathrm{mg}$ od) and one quarter the dose for patients with severe renal insufficiency (creatinine clearance $<30 \mathrm{ml} / \mathrm{min}$; i.e., $25 \mathrm{mg} \mathrm{qd}$ ). Hemodialysis only marginally removed sitagliptin in patients with ESRD and therefore it can be administered without concern over the timing of hemodialysis on sitagliptin disposition or clinical effects.

Similar to sitagliptin, vildagliptin is available either as a monotherapy or in a fixed dose combination with metformin and is given at the same maximum daily dose of $100 \mathrm{mg}$ (as $50 \mathrm{mg}$ twice-daily (bid)). Vildagliptin is effective for the treatment of T2DM, both alone and in combination with other glucose-lowering agents [16-19]. In contrast to sitagliptin, which is a competitive and dose-dependent DPP-4 inhibitor, vildagliptin is a 'substrateblocker' demonstrating different enzyme kinetics [20] Vildagliptin has a lower selectivity for DPP-4 ( $\left.\mathrm{IC}_{50}=100 \mathrm{nM}\right)$ than sitagliptin [17] and also cross-inhibits DPP-8 at micromolar concentrations $\left(\mathrm{IC}_{50}=9.0 \mu \mathrm{M}\right)[21]$.

Oral absorption of vildagliptin occurs within 3 hours [22] and the drug is rapidly and extensively metabolized, most likely in the liver. Almost one quarter of the oral dose is excreted unchanged in the urine (with one major metabolite that is almost exclusively renally excreted) $[22,23]$. Despite its hepatic clearance, cytochrome enzymes do not appear to be involved in drug metabolism [23] and investigations in patients with hepatic impairment versus those without revealed no association between hepatic function (as characterized by Child-Pugh classification) and the plasma pharmacokinetic profile of vildagliptin [24]. European labels thus recommend that vildagliptin should not be used in patients with hepatic impairment, including patients with pre-treatment alanine aminotransferase (ALT) or aspartate aminotransferase (AST) $>3 x$ the upper limit of normal. No dose adjustment is required in patients with mild renal impairment. In patients with moderate or severe renal impairment or with end-stage renal disease (ESRD), the recommended dose of vildagliptin is $50 \mathrm{mg}$ once daily [25].

Linagliptin was recently approved by the US Food and Drug Administration (FDA) and the European Medicines Agency for the treatment of T2DM. This competitive DPP-4 inhibitor [26] can be used as monotherapy or together with other glucose-lowering agents. In vitro, the linagliptin $\mathrm{IC}_{50}$ is approximately $1 \mathrm{nM}$, indicating a level of potency several times greater than values reported for other DPP-4 inhibitors [26]. The selectivity of linagliptin for DPP-4 is at least 10,000 times that of other dipeptidyl peptidases [26], markedly higher than values reported for sitagliptin [11] or vildagliptin [20].

In clinical trials, linagliptin demonstrated a safety and tolerability profile similar to that of placebo, with a very low risk for hypoglycemia [27-29]. The recommended dose is $5 \mathrm{mg}$ od [28], which effects mean reductions in DPP-4 activity of greater than $80 \%$ that last for at least 24 hours [28]. Disposition of linagliptin is unaffected by administration with food and it is mainly eliminated unchanged in the feces ( $>84 \%$ after oral application). Metabolism only makes a minor contribution to disposition and elimination, without involving the hepatic P450 system in any clinically meaningful manner [30]. Linagliptin binds tightly to plasma proteins, and its pharmacokinetics are significantly influenced by storable high affinity binding to DPP-4 in plasma and tissue. This leads to a long terminal half-life [31, 32]. Excretion in the urine is particularly low ( $<6 \%$ at an oral dosage of $5 \mathrm{mg} /$ day) [28], which may be a beneficial property in diabetic patients suffering from renal impairment.

Saxagliptin is a potent, selective and reversible DPP-4 inhibitor that is rapidly absorbed following oral administration. It differs from other gliptins in having an active metabolite (5-hydroxy saxagliptin; BMS-510849) that is also a selective, reversible and competitive 
DPP-4 inhibitor [33]. Although the metabolite is only one-half as potent as saxagliptin it is most likely responsible for the parent drug's extended pharmacodynamic activity. The metabolism of saxagliptin is primarily mediated by cytochrome P450 (particularly the $3 \mathrm{~A} 4 / 5$ isoenzyme) and so the European label for saxigliptin advises that the dose be reduced from $5 \mathrm{mg}$ od to $2.5 \mathrm{mg}$ od when it is administered with strong inhibitors of the cytochrome P450 $3 \mathrm{~A} 4 / 5$ isoenzyme [34]. However, there are no reported interactions between saxagliptin and three of the most frequently prescribed oral antidiabetic drugs: metformin, glyburide and pioglitazone [35].

Excretion of saxagliptin occurs mainly via the kidney, either as the parent drug (12$29 \%$ ) or the metabolite (21-52\%) [36]. Investigations in patients with and without renal impairment revealed that systemic exposure to saxagliptin and its metabolite (in terms of area under the plasma concentration-time curve: AUC) are associated with renal function, thus necessitating dose reduction of 50\% (2.5 mg daily) in patients with moderate or severe renal impairment, or ESRD [37]. In contrast to vildagliptin, saxagliptin and its metabolite undergo a considerable degree of clearance by hemodialysis [37]. Dose adjustment in patients with hepatic impairment (as characterized by Child-Pugh score) is not required; although plasma AUC of saxagliptin is higher in hepatically impaired individuals it is balanced by systemic exposure to its metabolite being lower [37].

Thus far only approved for use in Japan, alogliptin is a potent DPP-4 inhibitor (in vitro $\mathrm{IC}_{50}=6.9 \mathrm{nM}$ ) with a high degree of target selectivity (at least 10,000) compared with selectivity for other serum proteases such as DPP-2, DPP-8, DPP-9, fibroblast activation protein/seprase, prolyl endopeptidase and tryptase [38]. Absolute bioavailability of alogliptin in primates was high (72-88\%). Single doses of alogliptin in healthy subjects achieve peak plasma DPP-4 inhibition within 15 minutes, leveling off to around 80\% inhibition at 24 hours [39], confirming a once-daily posology. In humans alogliptin appears to be generally well tolerated $[39,40]$, and it can be administered independently of meals [41].

Excretion of alogliptin is primarily via the urine (60-71\% in the 72 hours after dosing) $[39,40]$. Overall metabolism is low, with M-I (N-demethylated) and M-II (N-acetylated) being the main metabolites and accounting for $<2 \%$ and $<6 \%$, respectively, of alogliptin concentrations in plasma and urine [39]. Systemic exposure to alogliptin is influenced by renal function with 1.7-fold, 2.1-fold, 3.2-fold, and 3.8-fold increases in exposure in patients with mild, moderate and severe renal impairment and ESRD, respectively, compared with healthy volunteers [42]. These findings strongly suggest that the dose should be reduced or excluded in patients with renal impairment, depending on the severity of the impairment. Data on the disposition of alogliptin in patients with hepatic impairment are sparse, but as metabolism is only a minor elimination pathway and excretion is mainly mediated by the kidneys, special precautions and dose adjustments in patients with hepatic impairment would seem to be unnecessary. No drug-drug interactions with clinically relevant drugs have yet been reported [43].

\section{Cardiovascular implications from non-clinical investigations}

Increased risk of heart failure, myocardial infarction, cardiac hypertrophy and coronary artery disease is often associated with the disease complex involving T2DM and hypertension that has been termed metabolic syndrome. It is generally believed that amelioration of the metabolic situation and reestablishing a more 'physiological' profile, including normalization of blood glucose, results in improvements in others factors of cardiovascular risk. As the DPP-4 enzyme is involved not only in the regulation of glucose but also several substrates known to have cardiovascular, renal and immune-modulating actions (Fig. 1), it is possible that this enzyme plays a key role in the development of metabolic syndrome. Thus long-term DPP-4 inhibition may have clinical benefits and/or consequences including cardioprotective actions. 


\section{Kidney Blood Pressure Research}

Kidney Blood Press Res 2012;36:65-84

DOI: $10.1159 / 000339028$

Published online: August 27, 2012

Hocher/Reichetzeder/Alter: Renal and Cardiac Effects of DPP4 Inhibitors.

In terms of their mechanism of action, DPP-4 inhibitors have no direct effect on glucose homeostasis per se, rather they serve to augment the normal physiological actions of GLP-1. As such, they have been viewed as working to return metabolic balance. Evidence from preclinical investigation suggests that DPP-4 inhibition may have beneficial effects on various metabolic indicators. In Zucker Diabetic Fatty (ZDF) rats, oral sitagliptin treatment for 6 weeks not only corrected the glycemic dysmetabolism (as measured by glucose and HbA1C levels), but also improved hypertrigylceridemia, inflammation (as measured by less pronounced hsCRP and IL-1 $\beta$ serum levels), oxidative stress and even diabetes-induced hypertension [44]. Furthermore, apparent normalization in markers of oxidative stress and inflammation was also seen in aorta samples taken from Otsuka Long-Evans Tokushima Fatty rats (OLETF rats) after 12 weeks of treatment with vildagliptin [45]. Changes were effected independently of blood pressure. When taken together with normalized expression of transforming growth factor- $\beta$, a marker of fibrosis, these data suggest that vildagliptin could play a protective role against vascular injury in diabetes, perhaps by attenuating the deleterious effects of the advanced glycation end products and oxidative stress axis.

Improvement in glycemic control associated with DPP-4 inhibition might account for the reductions in fibrosis markers and inflammation in the experiments described above in ZDF and OLETF rats $[44,45]$. However, there is evidence that DPP-4 inhibitors act directly on collagen metabolism [46] and modulate inflammation in ways that are independent of their glycemic effects [47-49]. In the non-diabetic 5/6 nephrectomy rat model of uremia, expression of fibrosis markers (tumor growth factor $\beta$, tissue inhibitor of metalloproteinases, collagen type $1 \alpha 1$ and $3 \alpha 1$ ) was significantly increased in the heart tissue of placebo-treated uremic rats, compared with SHAM animals. Short-term treatment with linagliptin for 4 days abolished this effect [50]. Furthermore, levels of mRNA for brain natriuretic peptide (BNP), a marker of cardiac function, were significantly reduced in heart tissue of linagliptin-treated animals, implying a protective effect on cardiac function [51]. In recent experiments, two pathways were identified as possibly being responsible for the cardio-protective effects of DPP-4 inhibitors. These were the reduced degradation of GLP-1 and type 1 stromal derived factor (SDF)-1 $\alpha$.

Receptors for GLP-1 are expressed in pancreatic $\beta$ cells and throughout the gut, lung, kidney, endothelium and heart [52,53], and GLP-1 receptor agonists appear to have beneficial effects on the cardiovascular system in humans and various animal models. Effects on contractility, blood pressure, cardiac output and cardioprotection appear to be independent of diabetes [54-61]. In several animal experiments beneficial effects of DPP-4 inhibitors were attributed to enhanced plasma GLP-1 levels. For example, treatment of obese, prediabetic rats with a DPP-4 inhibitor, PFK275-055, for 4 weeks resulted in a smaller infarct size following cardiac ischemia/reperfusion injury [55]. Interestingly, DPP-4 inhibition did not lead to a significant reduction in infarct size in non-obese rats, in which the infarct size was similar to the obese, PFK275-055 pre-treated animals. The findings suggest that the beneficial effects are only seen in animals with increased cardiovascular risk.

Other authors have observed marked improvements in the survival of genetically deficient DPP-4 (DPP-4\%) mice 4 weeks after ischemia/reperfusion injury compared with wild-type mice [62]. Cardiovascular function was preserved in DPP-4\% rats (versus wild-type animals) during endotoxemia and septic shock and these findings coincided with observations in wild-type animals pre-treated with the GLP-1 analogue, exendin-4 [63]. An alternative pathway through which GLP-1 may exert its effects has recently been identified [64]. GLP-1(9-36), the breakdown product of GLP-1 formed by DPP-4, appears to have effects on post-ischemic recovery of cardiac function and vasodilation mediated through a nitric oxide (NO)/cyclic guanosine monophosphate (cGMP)-dependent mechanism (i.e., not dependent on the GLP-1 receptor).

The chemokine SDF- $1 \alpha$ and its receptor, CXCR-4, participate in tissue repair by mediating migration of circulating stem or progenitor cells to sites of tissue injury $[65,66]$. It also exhibits paracrine and anti apoptotic effects during inflammation [67] and notably is a substrate of DPP-4. When healthy male Wistar rats were pre-treated with the DPP-4 inhibitor, BI 14361 


\section{Kidney Blood Pressure Research}

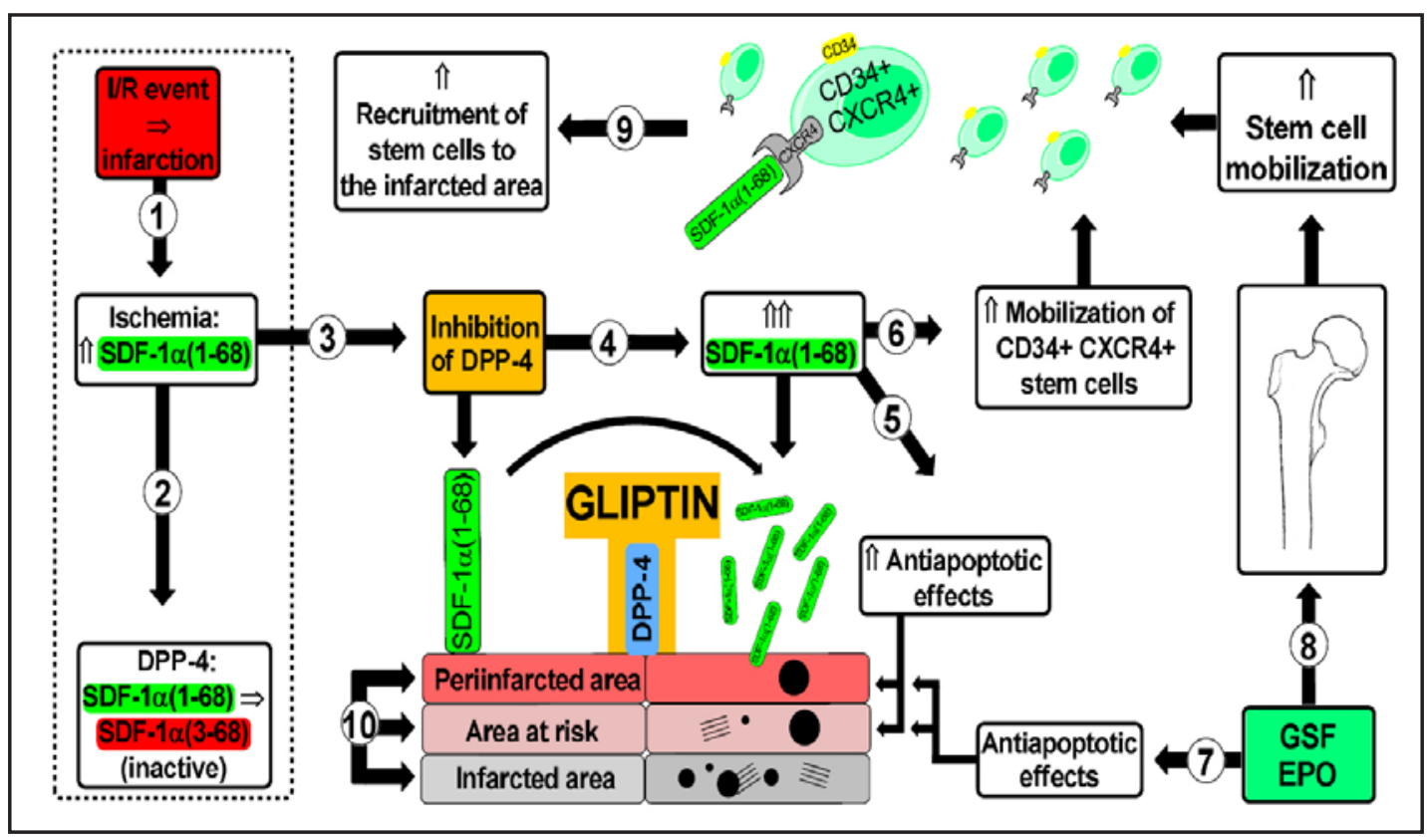

Fig. 2. Pathway of SDF1-alpha in I/R. An ischemia/reperfusion (I/R) event causes infarction of organ tissue (1). As a physiologic response during ischemia expression of SDF-1 $\alpha(1-68)$ is upregulated (1). Active DPP4 rapidly degrades SDF-1 $\alpha(1-68)$ to inactive SDF-1 $\alpha$ (3-68) (2). Blocking DPP-4 with Gliptins during I/R inhibits enzymatic degradation, leading to higher concentrations of SDF-1 $\alpha(1-68)$ in the infarcted area (4). SDF-1 $\alpha$ (1-68) has a direct antiapoptotic effect (5) on damaged cells and acts as a strong chemotaxin for CXCR4, leading to a mobilization of CD34+ CXCR4+ stem cells (6). Co-administration of cytokines (eg. GSF, EPO) acts synergistically with gliptins, as these compounds alike SDF-1 $\alpha(1-68)$ also have direct antiapoptotic properties (7) and mobilize stem cells from bone marrow. This enhancement of stem cell mobilization additionally increases SDF-1 $\alpha$ (1-68)-mediated recruitment of CD34+ CXCR4+ stem cells to the infarcted area (9). Via mechanisms not yet fully understood (direct antiapoptotic effects of SDF-1 $\alpha$ or GSF/EPO; paracrine antiapototic effects of homed stem cells; stem cell mediated neovascularisation; differentiation of homed stem cells to organ specific cells;) this new pharmacological treatment approach results in decreased infarct area, increased survival, improved organ function, reduced remodeling and improved neovascularisation (10). DPP-4, type 4 dipeptidyl peptidase; SDF-1, type 1 stromal derived factor; GSF, granulocyte stimulating factor; EPO, erythropoietin.

(or with vehicle), SDF-1 $\alpha$ significantly reduced infarct size, the infarct size relative to area at risk (AAR) and the extent of myocardial fibrosis after 7 days in healthy rats [68]. Inhibition of DPP-4 did not improve cardiac function as determined by echocardiography or cardiac catheterization. However, it might have been too early to expect improvements in cardiac function. The extent of reduction in infarct size would presumably have been masked by inflammatory and proliferative myocardial infiltrates during the first weeks after myocardial ischemia [68]. Nevertheless, cardiac immunohistochemistry revealed significantly increased expression of SDF-1 $\alpha$, CXCR-4, CD34, and c-kit as surrogate parameters of progenitor cells in healthy rats, compared with vehicle-treated ischemia/reperfusion injury rats and SHAM animals (see ref. [108] and Fig. 2 and 3). Work in mice has provided further evidence to support the hypothesis that reduced cleavage of SDF $1 \alpha$ leads to an enhanced recruitment of CXCR-4+ circulating progenitor cells and better cardiac outcome after ischemia/reperfusion injury.

An improvement in cardiac function was observed in DPP-4\% and diprotin -treated mice compared with vehicle treated wild-type mice [69]. The effects were more pronounced after co-administration of granulocyte colony-stimulating factor (G-CSF). Similar results were achieved in rats by transplantation of mesenchymal stem cells over-expressing CXCR 


\section{Kidney Blood Pressure Research}

Fig. 3. Quantitative analysis of cells that stained positive for CD34, c-kit, CXCR-4 and SDF- $1 \alpha$ 7 days after cardiac ischemia/reperfusion or sham intervention in rats treated with BI14361 or vehicle. DPP-4 inhibition via reduced cleavage of SDF-1 $\alpha$ might lead to an enhanced recruitment of CXCR-4+ circulating

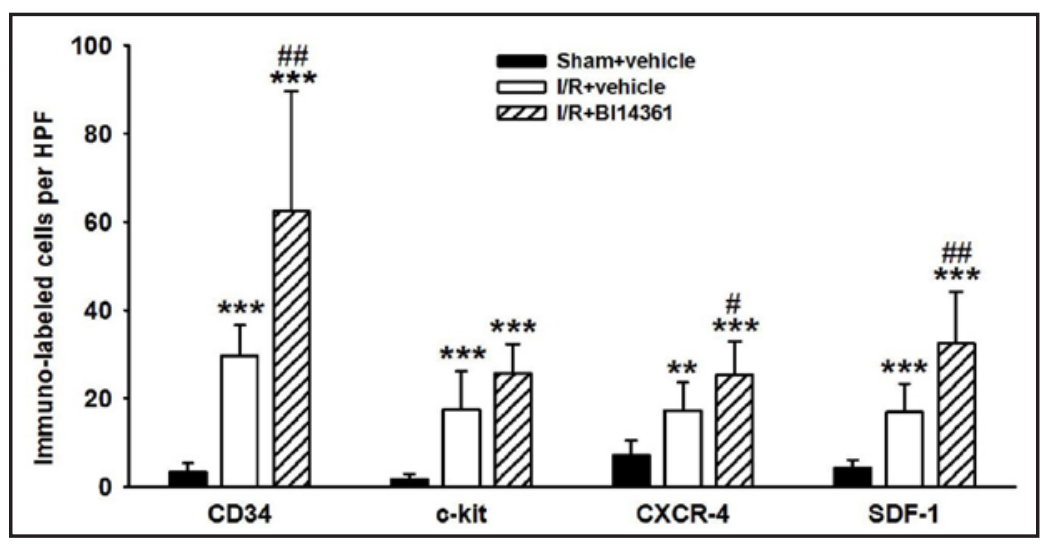
progenitor cells result-ing in better cardiac outcome after I/R. Data are means \pm standard deviation. $n=8-12$ per group [68]. SDF-1 $\alpha$, type 1 stromal derived factor alpha; HPF, high power field.

into diprotin A pre-treated rats 7 days after ischemia/reperfusion injury [70]. These findings imply a role for DPP-4 inhibition as a new pharmacological tool for tissue repair through enhanced stimulation and attraction of progenitor cells (Fig. 2); This is currently being investigated in a clinical setting [71].

\section{DPP-4 inhibition and blood pressure}

Observed effects of DPP-4 inhibition on arterial blood pressure appear to be contradictory. In diabetic ZDF rats, sitagliptin was associated with a significant normalization of blood pressure in ZDF rats with elevated blood pressure (versus non-diabetic ZDF rats) [44], whereas vildagliptin showed no influence on blood pressure in hypertensive OLEFT rats [45]. By contrast, DPP-4\% and exendin-4 attenuated the severe hypotension associated with endotoxemia and septic shock in wild-type rats [63]. These effects were considered most likely to be the result of the positive inotropic effects of GLP-1 (effected via the GLP-1 receptor).

One intriguing observation was the effect of sitagliptinin in spontaneously hypertensive rats (SHRs). Blood pressure in young (5 week-old) SHRs treated with the DPP-4 inhibitor was significantly lower than in vehicle-treated young SHR and was similar to that in young wild-type rats [72]. This effect was attributed to enhanced urinary flow and sodium excretion occurring as a result of decreased expression of the type 3 sodium-hydrogen transporter (NHE3) in the renal proximal tubule. Surprisingly, no effects were found in adult SHRs (older than 14 weeks). DPP-4 inhibition on neuropeptide (NPY) and peptide YY (PYY) may contribute to or account for the effect of these agents influence on blood pressure [73]. These peptides are agonists of the endogenous $Y(1)$ receptor (which mediates vasoconstriction) and are cleaved by DPP-4 to NPY(3-36) and PYY(3-36), respectively [74-76]. Single dose administration of the DPP-4 inhibitor, P32/98, did not influence blood pressure in adult SHRs, but blood pressure significantly increased in captopril and hydralazine pre-treated SHRs after P32/98 administration. This effect was abolished by the selective Y(1) receptor antagonist, BIBP 3226, whereas pre-treatment with the sympathicus blocker, chlorisondamine, did not affect blood pressure after P32/98 administration [73]. Interaction with this pathway may go some way to explaining the effects of sitagliptin in patients with metabolic syndrome [77]. Whereas sitagliptin lowered blood pressure versus placebo or submaximal angiotensin converting enzyme (ACE) inhibition ( $5 \mathrm{mg} /$ day) it was associated with activation of the sympathetic nervous system (as measured by heart rate and plasma norepinephrine concentrations) and, consequently, attenuation of the hypotensive response expected with maximal ACE inhibition $(10 \mathrm{mg} / \mathrm{kg} /$ day enalapril). Indeed, these results raise a potential concern over the use of DPP-4 inhibitors, particularly in hypertensive patients as gliptins are likely to be used in patients being treated with ACE inhibitors or sartans. Clearly, there is a 


\section{Kidney Blood Pressure Research}

Hocher/Reichetzeder/Alter: Renal and Cardiac Effects of DPP4 Inhibitors.

need for additional preclinical and clinical studies to better characterize the influence that DPP-4 inhibition can exert on blood pressure.

\section{Evidence of renal involvement}

The kidney is a major victim of the end organ damage associated with metabolic syndrome and T2DM, with hyperglycemia and hypertension being the main risk factors for the development of renal failure and ESRD. A degree of disease attenuation and/or slowing of disease progression can be achieved through intensive efforts to manage blood pressure and blood glucose. However, many patients will continue to develop diabetic nephropathy despite intensive efforts to achieve optimal control of these parameters, particularly in those patients who appear to be resistant to the beneficial effects that can be derived from ACE inhibition and/or angiotensin receptor blockade. New treatment paradigms are needed urgently considering the common association between T2DM and impaired renal function. Efforts to achieve metabolic control pharmacologically become increasingly difficult once renal function begins to deteriorate as many antidiabetic drugs are contraindicated. Agents, such as linagliptin, which appear most suitable since treatment can be continued without dose adjustment introduce alternatives in patients that may otherwise have remained untreated [50].

Potentially beneficial effects of DPP-4 inhibitors have been observed in STZ-eNOS $\%$ mice, believed to be a robust animal model of human diabetic nephropathy. In this model co-administration of linagliptin and the angiotensin receptor blocker (ARB) telmisartan, after only 11 weeks of treatment was associated with a marked reduction in albuminuria, an early predictor of diabetic nephropathy and cardiovascular morbidity [51]. Administration of telmisartan or linagliptin alone failed to lower significantly this important surrogate parameter [51]. Both plasma osteopontin (a marker of vascular calcification and fibrosis) and glomerulosclerosis (an indicator of morphologic changes in diabetic nephropathy) were significantly lower in linagliptin-treated animals as compared with placebo-treated diabetic mice. Furthermore, any treatment combination (linagliptin, telmisartan or both) lowered plasma TNF- $\alpha$ levels, an indicator of systemic inflammation. Notably, these results appeared early on in the development of diabetic nephropathy, during the hyperfiltration stage, and were independent of blood glucose and systolic blood pressure [51], implying that gliptins might have an additional benefit in diabetic patients resistant to ARBs. Changes that could similarly be considered to be of potential clinical benefit were observed in proteinuria, albuminuria, urinary albumin/creatinine ratio, creatinine clearance, interstitial volume, glomerulosclerosis and glomerular basement membrane thickness in streptozocin (STZ)induced diabetic rats after 24 weeks of treatment with the DPP-4 inhibitor LAF237 [78]. These effects appeared to be independent of blood glucose. Unlike earlier work, this study also observed improvements in glomerular filtration rates (GFRs), probably as a result of the longer period of study ( 24 weeks) than previous experiments. Further work will be required to elucidate whether these effects can be reproduced in a clinical setting and to establish whether they are truly independent of the benefits that can be achieved with ACE inhibitors and ARBs.

How DPP-4 inhibitors might exert their effects on the pathophysiological process leading to diabetic nephropathy has yet to be established. Clearly, DPP-4 inhibition and the GLP-1 receptor each play an important role in the process that appears to be independent of any associated impact on blood glucose. The relevance of the GLP-1 receptor is further supported by the observation that this receptor is expressed on podocytes (Fig. 4). In line with this observation are data showing that kidney protection in diabetic animals can be achieved with the GLP-1 analogue, exendin-4 [79]. The pathway comprising DPP-4, GLP-1 and the GLP-1 receptor presents several interesting features in the setting of diabetic nephropathy. First, expression of DPP-4 is up-regulated in several tissues (including the kidneys) during high-fat diet in rats with and without insulin deficiency, appearing to suggest an association 


\section{Kidney Blood Pressure Research}

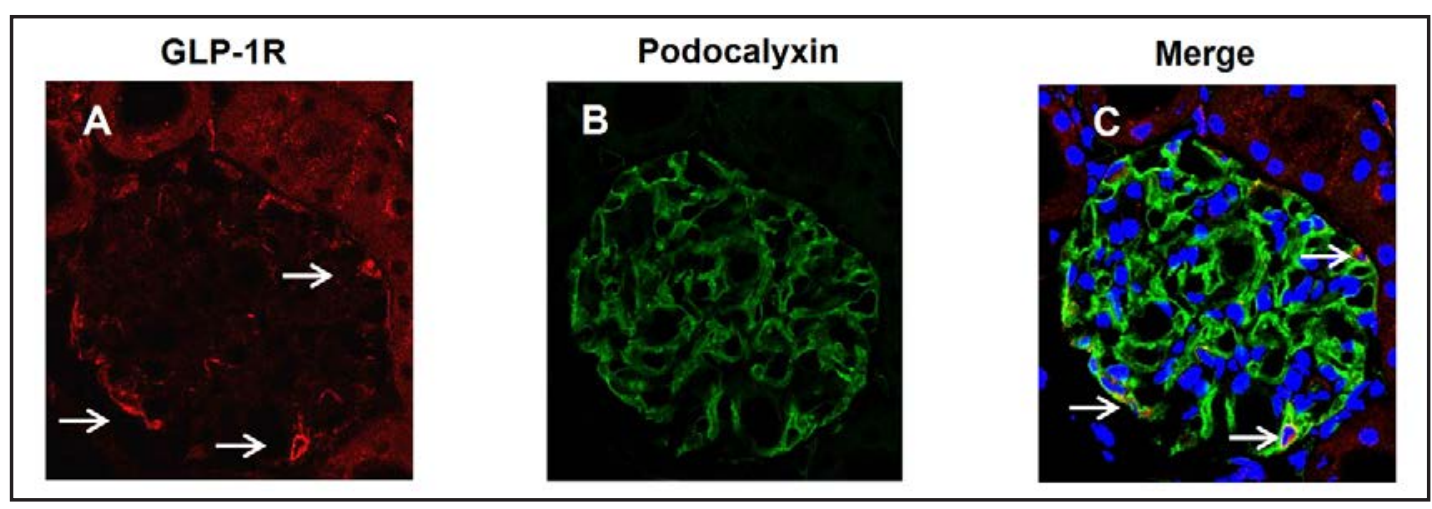

Fig. 4. Double immunofluorescence staining in healthy mice kidneys. GLP-1R (A), podocyte marker podocalyxin (B), and merging of the GLP-1R, podocalyxin and nuclei (DAPI) staining images (C). GLP-1R, type 1 glucagon like peptide receptor.

between the role of DPP-4 and the development of T2DM [80]. In addition, up-regulation of DPP-4 expression in renal glomeruli occurs during inflammation [81], and this usually accompanies the development of diabetes-induced glomerulosclerosis. A further observation is that GLP-1 receptors were down-regulated in renal glomeruli and tubules of diabetic rats and DPP-4 inhibition up-regulated their expression [78].

Little data are yet available addressing the effects of DPP-4 inhibition on the extent of ischemia/reperfusion injury. However, one study has investigated the renal protective effects of DPP-4 inhibition. Pre-treatment of diabetic animals with sitagliptin was associated with normalization of serum creatinine, blood urea nitrogen and expression of tissue injury markers following renal ischemia/reperfusion injury and was associated with the normalization of blood glucose to levels in non-diabetic control animals [82]. This finding implies that the apparently beneficial effects of DPP-4 inhibition are closely linked to the improvements in hyperglycemia.

A link observed between DPP-4 activity and the NHE3 exchanger provides us with an additional connection between glucose homeostasis, renal function and blood pressure [83]. In the renal proximal tubule the transporter mediates sodium reabsorption and is thus inextricably linked with volume homeostasis and blood pressure [84]. Inhibition of DPP-4, both in a proximal tubule cell line (in vitro) [85] and in normotensive wild-type Wistar rats (in vivo) [86] resulted in decreased NHE3 function. Treated rats were characterized by a significant increase in urine output, fractional sodium excretion and lithium clearance, an index of end-proximal tubule delivery. However, there was only a non-significant trend towards blood pressure reduction [86]. As outlined above, the effects of DPP-4 inhibition on blood pressure were different in the SHR where it was associated with a significant reduction in blood pressure in young pre-hypertensive SHR, but not in adult SHRs [72].

The functional link between DPP-4 inhibition and the NHE3 transporter could in some way explain how gliptins lower cardiac preload even beyond the classical DPP-4 mode of action, like prolonging the activity of endogenous BNP and atrial natriuretic peptide (ANP). The functional link between DPP-4 inhibition and the NHE3 transporter could go some way to explaining the means by which gliptins lower cardiac preload beyond effects achieved, for example, by prolonging the actions of endogenous BNP and atrial natriuretic peptide (ANP). The observation is of particular relevance as cardiac preload is often elevated and plasma DPP-4 appears to be upregulated in the kidneys of patients with T2DM [80]. However, exendin-4 also inhibits NHE3 activity [87], making it difficult to determine whether gliptinassociated effects on NHE3 function are mediated through reduced cleavage of GLP-1 or whether there were two different pathways operating independently, with the possibility that DPP-4 inhibition enhances GLP-1 action on NHE3.

On the other hand, DPP-4 inhibitors even enhanced the action of angiotensin-II on renal 


\section{Kidney Blood Pressure Research}

Hocher/Reichetzeder/Alter: Renal and Cardiac Effects of DPP4 Inhibitors.

vasoconstriction in SHR [88-90], suggesting possible deleterious effects in hypertensive individuals without ACE inhibitor treatment. These results are, however, limited to SHR, especially because the effects were attributed to PYY/NPY via the Y(1) receptors, and this pathway leads to vasoconstriction in SHR, but not in wild-type rats $[73,76]$.

\section{Renal and cardiovascular outcomes in clinical studies}

\section{Renal efficacy and safety}

Although there are only limited data on the tolerability and safety of long-term administration of gliptins, the profiles generally appear to be favorable. The most frequently reported adverse events associated with exposure to DPP-4 inhibitors are nasopharingitis and mild flu-like symptoms. Reporting of renal side effects under the controlled conditions of regulatory clinical trials has been rare. However, data from post-marketing studies indicate some rare cases of severe hypersensitivity reactions (including angioedema and anaphylaxia) and acute pancreatitis. In addition, the FDA has reported episodes of acute worsening of renal function and/or acute renal failure following exposure to inappropriate doses of sitagliptin in patients with renal insufficiency where there has been no appropriate dose-adjustment.

Route of elimination is one of the key differentiators of the marketed gliptins. Clearly, care should be taken when selecting one of the agents mainly excreted in the urine (e.g., sitagliptin, saxagliptin, vildagliptin or alogliptin) in patients with evidence of impaired renal function. Preclinical data indicate that sitagliptin and alogliptin accumulate in uremia and can cause a decrease in GFR [50]. Levels of systemic exposure to these drugs also correlated with markers of renal toxicity such as cystatin C, $\beta 2$-microglobulin, N-GAL and osteopontin [50]. Another study also reported that sitagliptin augments angiotensin II-induced renal vasoconstriction in kidneys from rats with metabolic syndrome [88]. There has been one case where sitagliptin was associated with worsening of renal function and rhabdomyolysis resulting from increasing circulating levels of simvastatin. This episode may have been the consequence of increasing competition for the renal human organic anion transporter (hOAT3: involved in active renal excretion of both drugs) in an already dysfunctional kidney [91]. The authors suggest that given the high likelihood of sitagliptin being co-administered with statins and other renally active medications, further study of the long-term safety of sitagliptin in renal insufficiency may be warranted.

In daily practice it is not uncommon for a patient's kidney function to be unknown or estimated sometime previously, raising a question mark over the clinical relevance of this information. Thus, it is perhaps unsurprising that there have been several cases where inappropriate dosing may have been exacerbated by declining renal function [15, $91,92]$. Clearly, the non-renally excreted DPP-4 inhibitor, linagliptin, remains appropriate in most patients without concern over possible drug accumulation consequent to renal impairment. Linagliptin may be further advantaged by its tight binding and high affinity for the DPP-4 enzyme and high degree of plasma protein binding, keeping circulating free drug concentrations relatively low. As linagliptin has only been available for clinical use since 2011 more time will be needed to determine whether these properties translate into practical therapeutic advantages over other gliptins.

Evidence from investigations with DPP-4 inhibitors in diabetic eNOS knockout mice [51], a model of diabetic nephropathy, suggest the potential of DPP-4 inhibitors to reduce albumin excretion. If it could be confirmed in humans this would translate into a significant benefit for patients with T2DM. Macro- and microalbuminuria are used to chart the progression of renal pathology. They are also predictive risk factors for non-fatal and fatal cardiovascular events in diabetic and non-diabetic patients. Interestingly, decreased rates of morbidity and mortality have been observed with therapeutic interventions that are associated with reductions in albumin excretion [93-97]. The effects of linagliptin in animal models appear to be over and above the effects of treatment with an angiotensin II receptor 


\section{Kidney Blood Pressure Research}

Fig. 5. Effect of the DPP-4 inhibitor Linagliptin on urinary albumin-to-creatinine ratio in patients with overt diabetic nephropathy. Four randomized, double-blind, 24-week, placebocontrolled trials of linagliptin on no, mono, or dual oral glucose-lowering background therapy had data available for urinary albumin-to-creatinine ratio (UACR) and were pooled for analysis $(n=2472)$. Participants were included in this analysis if they had: i) $\quad 30 \leq \mathrm{UACR} \leq 3000 \mathrm{mg} / \mathrm{g}$ creatinine; ii) stable treatment with ACE/ARBs $\geq 4$ weeks prior

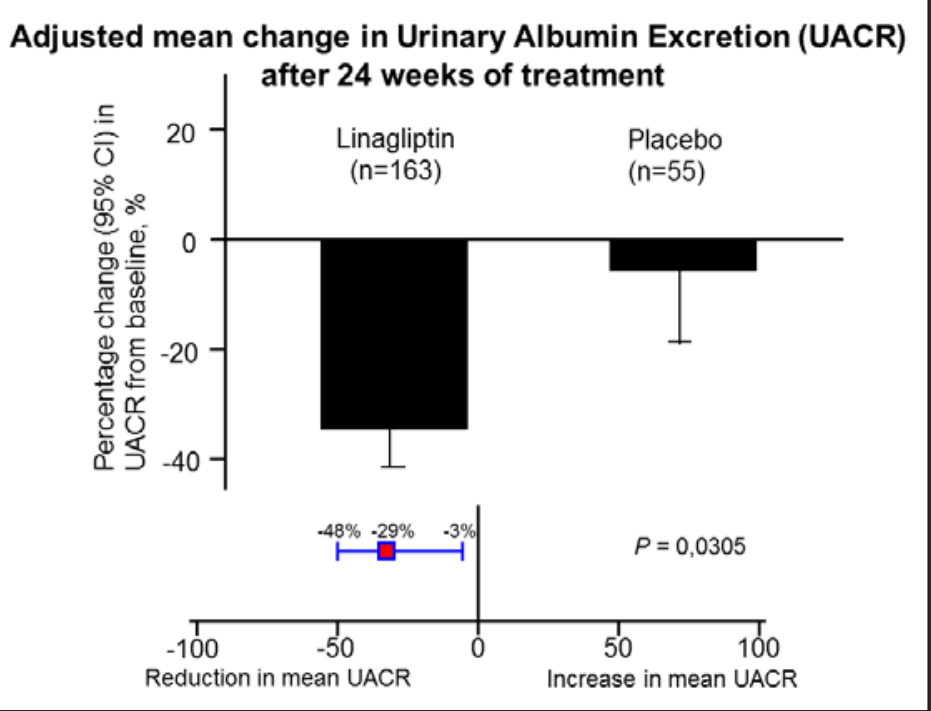
and during the trial; and iii) eGFR $>30 \mathrm{~mL} / \mathrm{min} / 1.73 \mathrm{~m}^{2}$. The endpoint was the percentage change in geometric mean UACR. In this analysis, 492 (19.9\%) patients met UACR and eGFR thresholds of whom $46 \%$ received stable ACE/ARB therapy (linagliptin $n=168$; placebo $n=59$ ). Median UACR were 76 versus $78 \mathrm{mg} / \mathrm{g}$ creatinine for the linagliptin and placebo groups, respectively. Linagliptin significantly lowered adjusted UACR by $33 \%$ (95\% CI: 22 to $42 \%$; $p<.05$ ) with a between group difference versus placebo of $-29 \%$ ( -3 to $-48 \%$; $\mathrm{p}$.05) [100].

antagonist [51]. This reduction in albumin excretion is thought to reflect beneficial effects of DPP-4 inhibition on podocytes (Fig. 4) in the context where podocyte loss is one of the first events leading to proteinuria [98]. Further investigation is required; however, the data available thus far appears promising. A recent, hypothesis-generating, open-label, 6-month study with sitagliptin (50 mg od) demonstrated a treatment-dependent decrease in urine albumin-to-creatinine ratio (UACR) in Japanese patients with T2DM [99]. A pooled analysis of data from four double-blind, placebo-controlled studies conducted with linagliptin for 6 months investigated changes in UACR (versus placebo). Patients were only eligible if they had microalbuminuria at baseline $(30<$ UACR $>300 \mathrm{mg} / \mathrm{g}$ creatinine) and were on a stable background treatment with either ACE inhibitors or ARBs. The analysis included data from 226 patients (linagliptin, $n=168$; placebo, $n=58$ ). Exposure to linagliptin was associated with statistically significant reductions in UACR versus placebo (Fig. 5) [100]. Clearly, further clinical studies are required to fully explore the anti-albuminuric and reno-protective potential of linagliptin.

\section{Cardiovascular efficacy and safety}

Since approval and market entry, DPP-4 inhibitors have been used widely in daily clinical practice. However, large outcome trials to establish long-term cardiovascular safety have yet to report or are still in the planning phase; it may be some years before data from these studies can be interpreted [101]. Given these circumstances, the most informative data on the cardiovascular safety of DPP-4 inhibitors currently available comes from meta-analyses performed on data gathered from studies conducted as part of the registration programs for individual compounds (Table 2).

A meta analysis of data for sitagliptin included 19 clinical trials and evaluated the information collected from 10,246 patients with T2DM [101]. Of this cohort, 82\% had elevated cardiovascular risk factors or evidence of cardiovascular disease in addition to their T2DM. The authors chose a composite endpoint, 'major adverse cardiac events' (MACE), as the primary outcome of their analysis. Performed retrospectively, the analysis did not 


\section{Kidney Blood Pressure Research}

Hocher/Reichetzeder/Alter: Renal and Cardiac Effects of DPP4 Inhibitors.

Table 2: Summary of cardiovascular risk reduction of all approved DPP4 inhibitors. Note that end-points are different among studies. Three studies are post-hoc analysis. An independent adjudication committee was also not always used.

\begin{tabular}{|c|c|c|c|c|}
\hline $\begin{array}{l}\text { Compound/ } \\
\text { reference }\end{array}$ & $\begin{array}{l}\text { Patients } \\
\text { analyzed }\end{array}$ & Primary end-point & Study design & $\begin{array}{l}\text { OR for outcome versus } \\
\text { competitor / } 95 \% \\
\text { confidence interval }\end{array}$ \\
\hline $\begin{array}{l}\text { Alogliptin } \\
\text { (111) }\end{array}$ & 3489 & $\begin{array}{l}\text { non-fatal MI, non- fatal } \\
\text { stroke, CV death }\end{array}$ & $\begin{array}{l}\text { Post-hoc analysis, } \\
\text { independent adjudication }\end{array}$ & $0.63(0.21-1.19)$ \\
\hline $\begin{array}{l}\text { Linagliptin } \\
(109)\end{array}$ & 5239 & $\begin{array}{l}\text { CV death, stroke, } \\
\text { hospitalization due to } \\
\text { angina }\end{array}$ & $\begin{array}{l}\text { Prespecified, prospective } \\
\text { analysis, independent } \\
\text { adjudication }\end{array}$ & $0.34(0.15-0.74)$ \\
\hline $\begin{array}{l}\text { Saxagliptin } \\
(103)\end{array}$ & 4607 & MI, stroke, CV death & $\begin{array}{l}\text { Prespecified, independent } \\
\text { adjudication }\end{array}$ & $0.42(0.23-0.89)$ \\
\hline $\begin{array}{l}\text { Sitagliptin } \\
(110)\end{array}$ & 10246 & MACE & $\begin{array}{l}\text { Post-hoc analysis, no } \\
\text { formal adjudication }\end{array}$ & $0.68(0.41-1.12)$ \\
\hline $\begin{array}{l}\text { Vildagliptin } \\
(102)\end{array}$ & 10988 & $\begin{array}{l}\text { Acute coronary } \\
\text { syndrome, TIA, stroke, } \\
\text { CV death }\end{array}$ & $\begin{array}{l}\text { Post-hoc analysis, } \\
\text { independent adjudication }\end{array}$ & $0.84(0.62-1.14)$ \\
\hline
\end{tabular}

seek to adjudicate on cardiovascular events. Event detection was based on adverse event reporting according to standard Medical Dictionary and glossary with medical definitions criteria used in clinical trials. Events incorporated within the MACE definition included: acute myocardial infarction, cerebellar infarction, cerebral infarction, cerebrovascular accident, hemorrhagic stroke, ischemic stroke, lacunar infarction, myocardial infarction, silent myocardial infarction, thalamic infarction and thrombotic stroke. The retrospective analysis reported 0.6 incident events per 100 patient-years in the sitagliptin group versus 0.9 in the non-exposed group (incidence rate ratio [sitagliptin/non-exposed] $=0.68[95 \%$ confidence interval (CI): 0.41, 1.12]).

The cardiovascular safety of vildagliptin was analyzed by retrospectively pooling data. In this instance, information was gathered from 25 Phase III studies, used either as monotherapy or combination therapy. Durations of treatment ranged from 12 weeks to 2 years [102]. The safety of vildagliptin [ $50 \mathrm{mg} \mathrm{qd}(\mathrm{N}=1393)$ or $50 \mathrm{mg}$ bid $(\mathrm{N}=6116)$ ] was assessed relative to a pool of all comparators [both placebo and active comparators $(\mathrm{N}=6061)]$. Cardiovascular events were judged in a prospective and blinded fashion by an independent adjudication committee. Relative to all comparators, the relative risk (RR) for the composite endpoint in this post-hoc analysis showed a consistent trend of $<1$ for both vildagliptin $50 \mathrm{mg}$ qd $[\mathrm{RR}=0.88 ; 95 \% \mathrm{CI}(0.37,2.11)]$ and vildagliptin $50 \mathrm{mg}$ bid $[\mathrm{RR}=0.84$; $95 \%$ CI $(0.62,1.14)]$. The results were consistent across subgroups stratified by age, gender and cardiovascular risk status, including the higher cardiovascular risk subgroups of elderly patients [RR for vildagliptin $50 \mathrm{mg}$ bid versus. all comparators $=1.04 ; 95 \% \mathrm{CI}(0.62,1.73)]$, males $[\mathrm{RR}=0.87 ; 95 \% \mathrm{CI}(0.60,1.24)]$ or patients with a high cardiovascular risk status [RR $=0.78 ; 95 \% \mathrm{CI}(0.51,1.19)]$.

Another study assessed the relative risk for cardiovascular events (death, myocardial infarction, stroke, revascularization procedures and cardiac ischemia) analyzing retrospectively eight randomized Phase II/III trials evaluating saxagliptin in patients with T2DM [103]. Four thousand six hundred and seven randomized and treated patients $(\mathrm{n}=$ 3356 treated with saxagliptin; $n=1251$, comparator [placebo, $n=656$; metformin, $n=328$; uptitrated glyburide, $\mathrm{n}=267$ ]) were included. Cardiovascular death/myocardial infarction / stroke events were reported by investigators in 41 patients: 23 (0.7\%), saxagliptin; 18 (1.4\%), comparator (RR, 95\% CI, 0.44 [0.24-0.82]).

All the above reported cardiovascular safety data were generated from post-hoc analyses of data from clinical development programs (Table 2). Limitations that need to be considered when interpreting these analyses include the fact that an intention to perform post hoc metaanalysis on the data collected during the development program was not a consideration when the study designs were being developed. In addition, studies did not always involve 


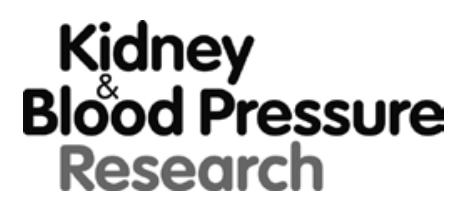

Kidney Blood Press Res 2012;36:65-84

\begin{tabular}{l|l}
\hline DOI: $10.1159 / 000339028$ & C 2012 S. Karger AG, Basel
\end{tabular}

Published online: August 27, 2012

www.karger.com/kbr

Hocher/Reichetzeder/Alter: Renal and Cardiac Effects of DPP4 Inhibitors.

cardiovascular event adjudication committees that could provide unbiased assessments of all cardiovascular events. However, during the linagliptin development program data collection and analysis was performed in a pre-specified and pre-defined manner. The cardiovascular safety profile of linagliptin versus comparators was evaluated based on prospectively captured cardiovascular events from eight Phase III randomized, double-blind, controlled trials. An independent cardiovascular event adjudication committee judged all events in a blinded manner. Although cardiovascular safety data for all DPP-4 inhibitors look promising and risk ratios so far tend to be below 1.0, we will, however, gain much stronger evidence with the ongoing DPP-4 inhibitor outcome trials: sitagliptin, vildagliptin [104] saxagliptin, linagliptin [105] and alogliptin [106], the first results are expected to emerge in 2014-15.

\section{Conclusion}

The class of DPP-4 inhibitors was developed and approved for the treatment of T2DM. Their primary mode of action is through inhibition of the degradation of incretions, such as GLP-1. Incretions are released from the small intestine after food intake and GLP-1 stimulates insulin secretion from the pancreas. Based on the glucose-dependent action of DPP-4 inhibitors they do not increase the risk of hypoglycemia and are weight neutral [112]. However, beyond its well-established actions on the pancreas GLP-1 further exerts direct effects on the heart, vessels and kidney, mainly via the GLP1-R. In addition, there are substrates of DPP-4 beyond incretins that have proven renal and cardiovascular effects such as BNP/ANP, NPY, PYY or SDF-1 $\alpha$. Preclinical evidence suggests that DPP-4 inhibitors may be beneficial in settings of acute renal failure and chronic kidney diseases such as diabetic nephropathy, but also in cardiac diseases such as myocardial infarction and heart failure. Interestingly, large cardiovascular meta-analyses of Phase II and III clinical trials of DPP-4 inhibitors all point in the same direction: a potential reduction of cardiovascular events in patients treated with this class. A pooled analysis on albumin excretion rates in clinical trials conducted with linagliptin raises the possibility of a direct renoprotective effect independent of improvements in glycemic control.

Inhibitors of the DPP-4 enzyme have been shown to have a very good overall safety and tolerability profile (Table 2), but for those excreted via the kidney dose adjustment is needed to avoid drug accumulation in patients with renal impairment. Linagliptin is currently the only DPP-4 inhibitor that is not excreted via the kidney and does not need dose adjustment at any degree of declining kidney function. This might be of clinical relevance, since a huge proportion of diabetic patients also suffer from kidney disease. The direct cardiac and renal effects seen in preclinical studies may offer additional opportunities for this new class of drugs beyond improvement in glycemic control. Further clinical phase 2 studies focusing primarily on suitable biomarkers as surrogates for clinical outcome $[107,108]$ and also adequately powered clinical phase 3 and 4 trials aiming to demonstrate clinically meaningful benefits - and safety - are warranted to explore the potential of DPP-4 inhibitors for in the treatment of acute kidney failure, chronic kidney failure and acute myocardial infarction as well as heart failure.

\section{Abbreviations}

AAR, area at risk; ACE, angiotensin converting enzyme; ANP, atrial natriuretic peptide; $\mathrm{ARB}$, angiotensin receptor blocker; bid, twice daily; BNP, brain natriuretic peptide; cGMP, cyclic guanosine monophosphate; CXCR-4,C-X-C chemokine receptor type 4; DDP-4, dipeptidyl peptidase 4; ESRD, end stage renal disease; G-CSF, granulocyte colony-stimulating factor; GFR, glomerular filtration rate; GIP, gastric inhibitory peptide; GLP-1, Glucagon like peptide type; GLP-1R, glucagon like peptide receptor type 1; HbA1c, glycated hemoglobin type 1A; hOAT3, human organic anion transporter; $\mathrm{IC}_{50}$, half maximal inhibitory concentration; MACE, 


\section{Kidney \\ Blood Pressure Research}

Kidney Blood Press Res 2012;36:65-84

\begin{tabular}{l|l}
\hline DOI: $10.1159 / 000339028$ & C 2012 S. Karger AG, Basel
\end{tabular}

Published online: August 27, 2012

www.karger.com/kbr

Hocher/Reichetzeder/Alter: Renal and Cardiac Effects of DPP4 Inhibitors.

major adverse cardiac events; NPY, neuropeptide Y; NHE3 sodium-hydrogen transporter type 3; NO, nitric oxide; od, once daily; OLETF, Otsuka Long-Evans Tokushima Fatty rats; PPAR, peroxisome proliferator-activated receptor; PYY, petide YY; SDF-1 $\alpha$, stromal derived factor type 1; SHR, spontaneously hypertensive rats; TNF- $\alpha$, tumor necrosis factor alpha; TGF- $\beta$, transforming growth factor beta; T2DM, type 2 diabetes mellitus; ZDF, Zucker Diabetic Fatty.

\section{Acknowledgements}

Dr. Berthold Hocher was supported by research grants from Boehringer Ingelheim GmbH, Germany, for the investigation of cardiac and renal effects of DPP4-inhibitors. The authors wish to thank Dr. Max v. Eynatten, Boehringer Ingelheim $\mathrm{GmbH}$, Germany, for providing data from their recently published abstract, see reference [100], needed for creating of figure 5.

\section{References}

1 Anon.: CDC - 2005 National Diabetes Fact Sheet - Publications - Diabetes DDT

-2 King H, Aubert RE, Herman WH: Global burden of diabetes, 1995-2025: prevalence, numerical estimates, and projections. Diabetes Care 1998;21:1414-1431.

3 Rodbard HW, Blonde L, Braithwaite SS, Brett EM, Cobin RH, Handelsman Y, Hellman R, Jellinger PS, Jovanovic LG, Levy P, Mechanick JI, Zangeneh F: American Association of Clinical Endocrinologists medical guidelines for clinical practice for the management of diabetes mellitus. Endocr Pract 2007;13:S1-68.

4 Gerstein HC, Miller ME, Byington RP, Goff DC Jr, Bigger JT, Buse JB, Cushman WC, Genuth S, Ismail-Beigi F, Grimm RH Jr, Probstfield JL, Simons-Morton DG, Friedewald WT: Effects of intensive glucose lowering in type 2 diabetes. N Engl J Med 2008;358:2545-2559.

5 Patel A, MacMahon S, Chalmers J, Neal B, Billot L, Woodward M, Marre M, Cooper M, Glasziou P, Grobbee D, Hamet P, Harrap S, Heller S, Liu L, Mancia G, Mogensen CE, Pan C, Poulter N, Rodgers A, Williams B, Bompoint S, de Galan BE, Joshi R, Travert F: Intensive blood glucose control and vascular outcomes in patients with type 2 diabetes. N Engl J Med 2008;358:2560-2572.

-6 Duckworth W, Abraira C, Moritz T, Reda D, Emanuele N, Reaven PD, Zieve FJ, Marks J, Davis SN, Hayward R, Warren SR, Goldman S, McCarren M, Vitek ME, Henderson WG, Huang GD: Glucose control and vascular complications in veterans with type 2 diabetes. N Engl J Med 2009;360:129-139.

7 Meinert CL, Knatterud GL, Prout TE, Klimt CR: A study of the effects of hypoglycemic agents on vascular complications in patients with adult-onset diabetes. II. Mortality results. Diabetes 1970;19:S789-830.

8 DeSouza C, Fonseca V: Therapeutic targets to reduce cardiovascular disease in type 2 diabetes. Nat Rev Drug Discov 2009;8:361-367.

$\checkmark 9$ Nissen SE, Wolski K: Effect of rosiglitazone on the risk of myocardial infarction and death from cardiovascular causes. N Engl J Med 2007;356:2457-2471.

$>10$ Kendall DM, Rubin CJ, Mohideen P, Ledeine J-M, Belder R, Gross J, Norwood P, O’Mahony M, Sall K, Sloan G, Roberts A, Fiedorek FT, DeFronzo RA: Improvement of glycemic control, triglycerides, and HDL cholesterol levels with muraglitazar, a dual (alpha/gamma) peroxisome proliferator-activated receptor activator, in patients with type 2 diabetes inadequately controlled with metformin monotherapy: A double-blind, randomized, pioglitazone-comparative study. Diabetes Care 2006;29:1016-1023.

-11 Kim D, Wang L, Beconi M, Eiermann GJ, Fisher MH, He H, Hickey GJ, Kowalchick JE, Leiting B, Lyons K, Marsilio F, McCann ME, Patel RA, Petrov A, Scapin G, Patel SB, Roy RS, Wu JK, Wyvratt MJ, Zhang BB, Zhu L, Thornberry NA, Weber AE: (2R)-4-oxo-4-[3-(trifluoromethyl)-5,6-dihydro[1,2,4]triazolo[4,3-a]pyrazin$7(8 \mathrm{H})$-yl]-1-(2,4,5-trifluorophenyl)butan-2-amine: a potent, orally active dipeptidyl peptidase IV inhibitor for the treatment of type 2 diabetes. J Med Chem 2005;48:141-151.

12 Lankas GR, Leiting B, Roy RS, Eiermann GJ, Beconi MG, Biftu T, Chan C-C, Edmondson S, Feeney WP, He H, Ippolito DE, Kim D, Lyons KA, Ok HO, Patel RA, Petrov AN, Pryor KA, Qian X, Reigle L, Woods A, Wu JK, Zaller D, Zhang X, Zhu L, Weber AE, Thornberry NA: Dipeptidyl peptidase IV inhibition for the treatment of type 2 diabetes: potential importance of selectivity over dipeptidyl peptidases 8 and 9. Diabetes 2005;54:29882994. 


\section{Kidney \\ Blood Pressure Research}

Kidney Blood Press Res 2012;36:65-84

DOI: 10.1159/000339028

Published online: August 27, 2012

(C) 2012 S. Karger AG, Base

www.karger.com/kbr

Hocher/Reichetzeder/Alter: Renal and Cardiac Effects of DPP4 Inhibitors.

-13 Herman GA, Stevens C, Van Dyck K, Bergman A, Yi B, De Smet M, Snyder K, Hilliard D, Tanen M, Tanaka W, Wang AQ Zeng W, Musson D, Winchell G, Davies MJ, Ramael S, Gottesdiener KM, Wagner JA: Pharmacokinetics and pharmacodynamics of sitagliptin, an inhibitor of dipeptidyl peptidase IV, in healthy subjects: results from two randomized, double-blind, placebo-controlled studies with single oral doses. Clin Pharmacol Ther 2005;78:675-688.

14 Herman GA, Bergman A, Stevens C, Kotey P, Yi B, Zhao P, Dietrich B, Golor G, Schrodter A, Keymeulen B, Lasseter KC, Kipnes MS, Snyder K, Hilliard D, Tanen M, Cilissen C, De Smet M, de Lepeleire I, Van Dyck K, Wang AQ Zeng W, Davies MJ, Tanaka W, Holst JJ, Deacon CF, Gottesdiener KM, Wagner JA: Effect of single oral doses of sitagliptin, a dipeptidyl peptidase-4 inhibitor, on incretin and plasma glucose levels after an oral glucose tolerance test in patients with type 2 diabetes. J Clin Endocrinol Metab 2006;91:4612-4619.

15 Bergman AJ, Cote J, Yi B, Marbury T, Swan SK, Smith W, Gottesdiener K, Wagner J, Herman GA: Effect of renal insufficiency on the pharmacokinetics of sitagliptin, a dipeptidyl peptidase-4 inhibitor. Diabetes Care 2007;30:1862-1864.

-16 Pi-Sunyer FX, Schweizer A, Mills D, Dejager S: Efficacy and tolerability of vildagliptin monotherapy in drugnaïve patients with type 2 diabetes. Diabetes Res Clin Pract 2007;76:132-138.

$\checkmark 17$ Bosi E, Camisasca RP, Collober C, Rochotte E, Garber AJ: Effects of vildagliptin on glucose control over 24 weeks in patients with type 2 diabetes inadequately controlled with metformin. Diabetes Care 2007;30:890-895.

18 Pratley RE, Jauffret-Kamel S, Galbreath E, Holmes D: Twelve-week monotherapy with the DPP-4 inhibitor vildagliptin improves glycemic control in subjects with type 2 diabetes. Horm Metab Res 2006;38:423-428.

19 Pratley RE, Rosenstock J, Pi-Sunyer FX, Banerji MA, Schweizer A, Couturier A, Dejager S: Management of type 2 diabetes in treatment-naive elderly patients: benefits and risks of vildagliptin monotherapy. Diabetes Care 2007;30:3017-3022.

-20 Villhauer EB, Brinkman JA, Naderi GB, Burkey BF, Dunning BE, Prasad K, Mangold BL, Russell ME, Hughes TE: 1-[[(3-hydroxy-1-adamantyl)amino]acetyl]-2-cyano-(S)-pyrrolidine: a potent, selective, and orally bioavailable dipeptidyl peptidase IV inhibitor with antihyperglycemic properties. J Med Chem 2003;46:2774-2789.

21 Brandt I, Joossens J, Chen X, Maes M-B, Scharpé S, De Meester I, Lambeir A-M: Inhibition of dipeptidyl-peptidase IV catalyzed peptide truncation by Vildagliptin ((2S)-\{[(3-hydroxyadamantan-1yl)amino]acetyl\}-pyrrolidine-2-carbonitrile). Biochem Pharmacol 2005;70:134-143.

-22 He Y-L, Sabo R, Campestrini J, Wang Y, Ligueros-Saylan M, Lasseter KC, Dilzer SC, Howard D, Dole WP: The influence of hepatic impairment on the pharmacokinetics of the dipeptidyl peptidase IV (DPP-4) inhibitor vildagliptin. Eur J Clin Pharmacol 2007;63:677-686.

-23 He H, Tran P, Yin H, Smith H, Batard Y, Wang L, Einolf H, Gu H, Mangold JB, Fischer V, Howard D: Absorption, metabolism, and excretion of [14C]vildagliptin, a novel dipeptidyl peptidase 4 inhibitor, in humans. Drug Metab Dispos 2009;37:536-544.

24 He Y-L, Sadler BM, Sabo R, Balez S, Wang Y, Campestrini J, Laurent A, Ligueros-Saylan M, Howard D: The absolute oral bioavailability and population-based pharmacokinetic modelling of a novel dipeptidylpeptidase-IV inhibitor, vildagliptin, in healthy volunteers. Clin Pharmacokinet 2007;46:787-802. GALVUS®: SUMMARY OF PRODUCT CHARACTERISTICS

-26 Thomas L, Eckhardt M, Langkopf E, Tadayyon M, Himmelsbach F, Mark M: (R)-8-(3-amino-piperidin-1yl)-7-but-2-ynyl-3-methyl-1-(4-methyl-quinazolin-2-ylmethyl)-3,7-dihydro-purine-2,6-dione (BI 1356), a novel xanthine-based dipeptidyl peptidase 4 inhibitor, has a superior potency and longer duration of action compared with other dipeptidyl peptidase-4 inhibitors. J Pharmacol Exp Ther 2008;325:175-182.

-27 Graefe-Mody EU, Padula S, Ring A, Withopf B, Dugi KA: Evaluation of the potential for steady-state pharmacokinetic and pharmacodynamic interactions between the DPP-4 inhibitor linagliptin and metformin in healthy subjects. Curr Med Res Opin 2009;25:1963-1972.

-28 Hüttner S, Graefe-Mody EU, Withopf B, Ring A, Dugi KA: Safety, tolerability, pharmacokinetics, and pharmacodynamics of single oral doses of BI 1356, an inhibitor of dipeptidyl peptidase 4, in healthy male volunteers. J Clin Pharmacol 2008;48:1171-1178.

29 Heise T, Graefe-Mody EU, Hüttner S, Ring A, Trommeshauser D, Dugi KA: Pharmacokinetics, pharmacodynamics and tolerability of multiple oral doses of linagliptin, a dipeptidyl peptidase-4 inhibitor in male type 2 diabetes patients. Diabetes Obes Metab 2009;11:786-794.

30 Blech S, Ludwig-Schwellinger E, Gräfe-Mody EU, Withopf B, Wagner K: The metabolism and disposition of the oral dipeptidyl peptidase-4 inhibitor, linagliptin, in humans. Drug Metab Dispos 2010;38:667-678. 


\section{Kidney \\ Blood Pressure Research}

Kidney Blood Press Res 2012;36:65-84

DOI: $10.1159 / 000339028$

Published online: August 27, 2012

(C) 2012 S. Karger AG, Base

www.karger.com/kbr

Hocher/Reichetzeder/Alter: Renal and Cardiac Effects of DPP4 Inhibitors.

-31 Fuchs H, Tillement J-P, Urien S, Greischel A, Roth W: Concentration-dependent plasma protein binding of the novel dipeptidyl peptidase 4 inhibitor BI 1356 due to saturable binding to its target in plasma of mice, rats and humans. J Pharm Pharmacol 2009;61:55-62.

-32 Retlich S, Withopf B, Greischel A, Staab A, Jaehde U, Fuchs H: Binding to dipeptidyl peptidase-4 determines the disposition of linagliptin (BI 1356)--investigations in DPP-4 deficient and wildtype rats. Biopharm Drug Dispos 2009;30:422-436.

33 Fura A, Khanna A, Vyas V, Koplowitz B, Chang S-Y, Caporuscio C, Boulton DW, Christopher LJ, Chadwick KD, Hamann LG, Humphreys WG, Kirby M: Pharmacokinetics of the dipeptidyl peptidase 4 inhibitor saxagliptin in rats, dogs, and monkeys and clinical projections. Drug Metab Dispos 2009;37:1164-1171.

34 ONGLYZA®: SUMMARY OF PRODUCT CHARACTERISTICS

-35 Patel CG, Kornhauser D, Vachharajani N, Komoroski B, Brenner E, Handschuh del Corral M, Li L, Boulton DW: Saxagliptin, a potent, selective inhibitor of DPP-4, does not alter the pharmacokinetics of three oral antidiabetic drugs (metformin, glyburide or pioglitazone) in healthy subjects. Diabetes Obes Metab 2011;13:604-614.

36 Boulton D, Geraldes M: Safety, Tolerability, Pharmacokinetics and Pharmacodynamics of Once-Daily Oral Doses of Saxagliptin for 2 Weeks in Type 2 Diabetic and Healthy Subjects. in: 67th Annual Scientific Sessions of the American Diabetes Association. 2007.

-37 Boulton DW, Li L, Frevert EU, Tang A, Castaneda L, Vachharajani NN, Kornhauser DM, Patel CG: Influence of renal or hepatic impairment on the pharmacokinetics of saxagliptin. Clin Pharmacokinet 2011;50:253265.

-38 Lee B, Shi L, Kassel DB, Asakawa T, Takeuchi K, Christopher RJ: Pharmacokinetic, pharmacodynamic, and efficacy profiles of alogliptin, a novel inhibitor of dipeptidyl peptidase-4, in rats, dogs, and monkeys. Eur J Pharmacol 2008;589:306-314.

-39 Christopher R, Covington P, Davenport M, Fleck P, Mekki QA, Wann ER, Karim A: Pharmacokinetics, pharmacodynamics, and tolerability of single increasing doses of the dipeptidyl peptidase-4 inhibitor alogliptin in healthy male subjects. Clin Ther 2008;30:513-527.

40 Covington P, Christopher R, Davenport M, Fleck P, Mekki QA, Wann ER, Karim A: Pharmacokinetic, pharmacodynamic, and tolerability profiles of the dipeptidyl peptidase- 4 inhibitor alogliptin: a randomized, double-blind, placebo-controlled, multiple-dose study in adult patients with type 2 diabetes. Clin Ther 2008;30:499-512.

41 Karim A, Covington P, Christopher R, Davenport M, Fleck P, Li X, Wann E, Mekki Q: Pharmacokinetics of alogliptin when administered with food, metformin, or cimetidine: a two-phase, crossover study in healthy subjects. Int J Clin Pharmacol Ther 2010;48:46-58.

42 Karim A, Fleck P, Hetman L: Single-Dose Pharmacokinetics of the Dipeptidyl Peptidase-4 Inhibitor Alogliptin in Subjects with Renal Impairment. in: 68th Annual Scientific Sessions of the American Diabetes Association. 2008.

43 Karim A, Laurent A, Munsaka M, Wann E, Fleck P, Mekki Q: Coadministration of pioglitazone or glyburide and alogliptin: pharmacokinetic drug interaction assessment in healthy participants. J Clin Pharmacol 2009;49:1210-1219.

-44 Ferreira L, Teixeira-de-Lemos E, Pinto F, Parada B, Mega C, Vala H, Pinto R, Garrido P, Sereno J, Fernandes R, Santos P, Velada I, Melo A, Nunes S, Teixeira F, Reis F: Effects of sitagliptin treatment on dysmetabolism, inflammation, and oxidative stress in an animal model of type 2 diabetes (ZDF rat). Mediators Inflamm 2010;2010:592760.

45 Matsui T, Nishino Y, Takeuchi M, Yamagishi S: Vildagliptin blocks vascular injury in thoracic aorta of diabetic rats by suppressing advanced glycation end product-receptor axis. Pharmacol Res 2011;63:383388.

46 Jost MM, Lamerz J, Tammen H, Menzel C, De Meester I, Lambeir A-M, Augustyns K, Scharpé S, Zucht HD, Rose H, Jürgens M, Schulz-Knappe P, Budde P: In vivo profiling of DPP4 inhibitors reveals alterations in collagen metabolism and accumulation of an amyloid peptide in rat plasma. Biochem Pharmacol 2009;77:228-237.

47 Dobrian AD, Ma Q, Lindsay JW, Leone KA, Ma K, Coben J, Galkina EV, Nadler JL: Dipeptidyl peptidase IV inhibitor sitagliptin reduces local inflammation in adipose tissue and in pancreatic islets of obese mice. Am J Physiol Endocrinol Metab 2011;300:E410-E421.

48 Korom S, De Meester I, Stadlbauer TH, Chandraker A, Schaub M, Sayegh MH, Belyaev A, Haemers A, Scharpé S, Kupiec-Weglinski JW: Inhibition of CD26/dipeptidyl peptidase IV activity in vivo prolongs cardiac allograft survival in rat recipients. Transplantation 1997;63:1495-1500. 


\section{Kidney \\ Blood Pressure Research}

Kidney Blood Press Res 2012;36:65-84

\begin{tabular}{l|l}
\hline DOI: $10.1159 / 000339028$ & (c 2012 S. Karger AG, Basel
\end{tabular}

Published online: August 27, 2012

www.karger.com/kbr

-49 Korom S, de Meester I, Belyaev A, Schmidbauer G, Schwemmle K: CD26/DPP IV in experimental and clinical organ transplantation. Adv Exp Med Biol 2003;524:133-143.

50 Chaykovska L, von Websky K, Rahnenführer J, Alter M, Heiden S, Fuchs H, Runge F, Klein T, Hocher B: Effects of DPP-4 inhibitors on the heart in a rat model of uremic cardiomyopathy. PLoS ONE 2011;6: e27861.

51 Alter M, Ott I, von Websky K, Tsuprykov O, Sharkovska Y, Krause-Relle K, Raila J, Henze A, Klein T, Hocher B: DPP-4 inhibition on top of angiotensin receptor blockade offers a new therapeutic approach for diabetic nephropathy. Kidney Blood Press Res DOI: 10.1159/000341487.

52 Bullock BP, Heller RS, Habener JF: Tissue distribution of messenger ribonucleic acid encoding the rat glucagon-like peptide-1 receptor. Endocrinology 1996;137:2968-2978.

53 Wei Y, Mojsov S: Distribution of GLP-1 and PACAP receptors in human tissues. Acta Physiol Scand 1996;157:355-357.

54 Huisamen B, Genade S, Lochner A: Signalling pathways activated by glucagon-like peptide-1 (7-36) amide in the rat heart and their role in protection against ischaemia. Cardiovasc J Afr 2008;19:77-83.

55 Huisamen B, Genis A, Marais E, Lochner A: Pre-treatment with a DPP-4 inhibitor is infarct sparing in hearts from obese, pre-diabetic rats. Cardiovasc Drugs Ther 2011;25:13-20.

56 Gardiner SM, March JE, Kemp PA, Bennett T, Baker DJ: Possible involvement of GLP-1(9-36) in the regional haemodynamic effects of GLP-1(7-36) in conscious rats. Br J Pharmacol 2010;161:92-102.

57 Sokos GG, Nikolaidis LA, Mankad S, Elahi D, Shannon RP: Glucagon-like peptide-1 infusion improves left ventricular ejection fraction and functional status in patients with chronic heart failure. J Card Fail 2006;12:694-699.

58 Nikolaidis LA, Doverspike A, Hentosz T, Zourelias L, Shen Y-T, Elahi D, Shannon RP: Glucagon-like peptide1 limits myocardial stunning following brief coronary occlusion and reperfusion in conscious canines. J Pharmacol Exp Ther 2005;312:303-308.

59 Nikolaidis LA, Elahi D, Hentosz T, Doverspike A, Huerbin R, Zourelias L, Stolarski C, Shen Y, Shannon RP: Recombinant glucagon-like peptide-1 increases myocardial glucose uptake and improves left ventricular performance in conscious dogs with pacing-induced dilated cardiomyopathy. Circulation 2004;110:955961.

60 Nikolaidis LA, Mankad S, Sokos GG, Miske G, Shah A, Elahi D, Shannon RP: Effects of glucagon-like peptide-1 in patients with acute myocardial infarction and left ventricular dysfunction after successful reperfusion. Circulation 2004;109:962-965.

-61 Bose AK, Mocanu MM, Carr RD, Brand CL, Yellon DM: Glucagon-like peptide 1 can directly protect the heart against ischemia/reperfusion injury. Diabetes 2005;54:146-151.

-62 Sauvé M, Ban K, Momen MA, Zhou Y-Q Henkelman RM, Husain M, Drucker DJ: Genetic Deletion or Pharmacological Inhibition of Dipeptidyl Peptidase-4 Improves Cardiovascular Outcomes After Myocardial Infarction in Mice. Diabetes 2010;59:1063 -1073.

-63 Ku H-C, Chen W-P, Su M-J: GLP-1 signaling preserves cardiac function in endotoxemic Fischer 344 and DPP4-deficient rats. Naunyn Schmiedebergs Arch Pharmacol 2010;382:463-474.

64 Ban K, Noyan-Ashraf MH, Hoefer J, Bolz S-S, Drucker DJ, Husain M: Cardioprotective and vasodilatory actions of glucagon-like peptide 1 receptor are mediated through both glucagon-like peptide 1 receptordependent and -independent pathways. Circulation 2008;117:2340-2350.

-65 Askari AT, Unzek S, Popovic ZB, Goldman CK, Forudi F, Kiedrowski M, Rovner A, Ellis SG, Thomas JD, DiCorleto PE, Topol EJ, Penn MS: Effect of stromal-cell-derived factor 1 on stem-cell homing and tissue regeneration in ischaemic cardiomyopathy. Lancet 2003;362:697-703.

-66 Kollet O, Shivtiel S, Chen Y-Q Suriawinata J, Thung SN, Dabeva MD, Kahn J, Spiegel A, Dar A, Samira S, Goichberg P, Kalinkovich A, Arenzana-Seisdedos F, Nagler A, Hardan I, Revel M, Shafritz DA, Lapidot T: HGF, SDF-1, and MMP-9 are involved in stress-induced human CD34+ stem cell recruitment to the liver. J Clin Invest 2003;112:160-169.

67 Stokman G, Stroo I, Claessen N, Teske GJD, Florquin S, Leemans JC: SDF-1 provides morphological and functional protection against renal ischaemia/reperfusion injury. Nephrology Dialysis Transplantation 2010;25:3852 -3859.

68 Hocher B, Sharkovska Y, Mark M, Klein T, Pfab T: The novel DPP-4 inhibitors linagliptin and BI 14361 reduce infarct size after myocardial ischemia/reperfusion in rats. Int J Cardiol DOI: $\underline{10.1016 /}$ j.ijcard.2011.12.007. 


\section{Kidney \\ Blood Pressure Research}

Kidney Blood Press Res 2012;36:65-84

\begin{tabular}{l|l}
\hline DOI: $10.1159 / 000339028$ & (C) 2012 S. Karger AG, Basel
\end{tabular}

Published online: August 27, 2012

www.karger.com/kbr

Hocher/Reichetzeder/Alter: Renal and Cardiac Effects of DPP4 Inhibitors.

-69 Zaruba M-M, Theiss HD, Vallaster M, Mehl U, Brunner S, David R, Fischer R, Krieg L, Hirsch E, Huber B, Nathan P, Israel L, Imhof A, Herbach N, Assmann G, Wanke R, Mueller-Hoecker J, Steinbeck G, Franz W-M: Synergy between CD26/DPP-IV inhibition and G-CSF improves cardiac function after acute myocardial infarction. Cell Stem Cell 2009;4:313-323.

-70 Zhang D, Huang W, Dai B, Zhao T, Ashraf A, Millard RW, Ashraf M, Wang Y: Genetically manipulated progenitor cell sheet with diprotin A improves myocardial function and repair of infarcted hearts. Am J Physiol Heart Circ Physiol 2010;299:H1339-1347.

-71 Theiss HD, Brenner C, Engelmann MG, Zaruba M-M, Huber B, Henschel V, Mansmann U, Wintersperger B, Reiser M, Steinbeck G, Franz W-M: Safety and efficacy of SITAgliptin plus GRanulocyte-colony-stimulating factor in patients suffering from Acute Myocardial Infarction (SITAGRAMI-Trial)-rationale, design and first interim analysis. Int J Cardiol 2010;145:282-284.

72 Pacheco BP, Crajoinas RO, Couto GK, Davel APC, Lessa LM, Rossoni LV, Girardi AC: Dipeptidyl peptidase IV inhibition attenuates blood pressure rising in young spontaneously hypertensive rats. J Hypertens 2011;29:520-528.

73 Jackson EK, Dubinion JH, Mi Z: Effects of dipeptidyl peptidase iv inhibition on arterial blood pressure. Clin Exp Pharmacol Physiol 2008;35:29-34.

74 Mentlein R, Dahms P, Grandt D, Krüger R: Proteolytic processing of neuropeptide Y and peptide YY by dipeptidyl peptidase IV. Regul Pept 1993;49:133-144.

75 Berglund MM, Hipskind PA, Gehlert DR: Recent developments in our understanding of the physiological role of PP-fold peptide receptor subtypes. Exp Biol Med (Maywood) 2003;228:217-244.

-76 Dubinion JH, Mi Z, Zhu C, Gao L, Jackson EK: Pancreatic polypeptide-fold peptide receptors and angiotensin II-induced renal vasoconstriction. Hypertension 2006;47:545-551.

-77 Marney A, Kunchakarra S, Byrne L, Brown NJ: Interactive hemodynamic effects of dipeptidyl peptidase-IV inhibition and angiotensin-converting enzyme inhibition in humans. Hypertension 2010;56:728-733.

78 Liu WJ, Xie SH, Liu YN, Kim W, Jin HY, Park SK, Shao YM, Park TS: Dipeptidyl peptidase IV inhibitor attenuates kidney injury in streptozotocin-induced diabetic rats. J Pharmacol Exp Ther 2012;340:248-255.

-79 Kodera R, Shikata K, Kataoka HU, Takatsuka T, Miyamoto S, Sasaki M, Kajitani N, Nishishita S, Sarai K, Hirota D, Sato C, Ogawa D, Makino H: Glucagon-like peptide-1 receptor agonist ameliorates renal injury through its anti-inflammatory action without lowering blood glucose level in a rat model of type 1 diabetes. Diabetologia 2011;54:965-978.

80 Yang J, Campitelli J, Hu G, Lin Y, Luo J, Xue C: Increase in DPP-IV in the intestine, liver and kidney of the rat treated with high fat diet and streptozotocin. Life Sci 2007;81:272-279.

-81 Stefanovic V, Ardaillou N, Vlahovic P, Placier S, Ronco P, Ardaillou R: Interferon-gamma induces dipeptidylpeptidase IV expression in human glomerular epithelial cells. Immunology 1993;80:465-470.

82 Vaghasiya J, Sheth N, Bhalodia Y, Manek R: Sitagliptin protects renal ischemia reperfusion induced renal damage in diabetes. Regul Pept 2011;166:48-54.

83 Girardi AC, Degray BC, Nagy T, Biemesderfer D, Aronson PS: Association of $\mathrm{Na}(+)-\mathrm{H}(+)$ exchanger isoform NHE3 and dipeptidyl peptidase IV in the renal proximal tubule. J Biol Chem 2001;276:46671-46677.

84 Schultheis PJ, Clarke LL, Meneton P, Miller ML, Soleimani M, Gawenis LR, Riddle TM, Duffy JJ, Doetschman T, Wang T, Giebisch G, Aronson PS, Lorenz JN, Shull GE: Renal and intestinal absorptive defects in mice lacking the NHE3 Na+/H+ exchanger. Nat Genet 1998;19:282-285.

85 Girardi ACC, Knauf F, Demuth H-U, Aronson PS: Role of dipeptidyl peptidase IV in regulating activity of $\mathrm{Na}+/ \mathrm{H}+$ exchanger isoform NHE3 in proximal tubule cells. Am J Physiol, Cell Physiol 2004;287:C12381245.

-86 Girardi ACC, Fukuda LE, Rossoni LV, Malnic G, Rebouças NA: Dipeptidyl peptidase IV inhibition downregulates $\mathrm{Na}+$ - H+ exchanger NHE3 in rat renal proximal tubule. Am J Physiol Renal Physiol 2008;294:F414-422.

87 Carraro-Lacroix LR, Malnic G, Girardi ACC: Regulation of Na+/H+ exchanger NHE3 by glucagon-like peptide 1 receptor agonist exendin-4 in renal proximal tubule cells. Am J Physiol Renal Physiol 2009;297:F16471655.

-88 Tofovic DS, Bilan VP, Jackson EK: Sitagliptin augments angiotensin II-induced renal vasoconstriction in kidneys from rats with metabolic syndrome. Clin Exp Pharmacol Physiol 2010;37:689-691.

89 Jackson EK, Mi Z: Sitagliptin augments sympathetic enhancement of the renovascular effects of angiotensin II in genetic hypertension. Hypertension 2008;51:1637-1642. 


\section{Kidney \\ Blood Pressure Research}

Kidney Blood Press Res 2012;36:65-84

\begin{tabular}{l|l}
\hline DOI: $10.1159 / 000339028$ & (c) 2012 S. Karger AG, Basel
\end{tabular}

Published online: August 27, 2012

www.karger.com/kbr

-90 Jackson EK, Zhang M, Liu W, Mi Z: Inhibition of renal dipeptidyl peptidase IV enhances peptide YY1-36induced potentiation of angiotensin II-mediated renal vasoconstriction in spontaneously hypertensive rats. J Pharmacol Exp Ther 2007;323:431-437.

-91 Kao DP, Kohrt HE, Kugler J: Renal failure and rhabdomyolysis associated with sitagliptin and simvastatin use. Diabet Med 2008;25:1229-1230.

$\checkmark 92$ Lestner JM, Baburaj R, Edwards CMB: Renal impairment with sitagliptin: is there a need for active monitoring of potential renal toxicity? Br J Hosp Med (Lond) 2011;72:412-413.

$>93$ Mogensen CE, Keane WF, Bennett PH, Jerums G, Parving HH, Passa P, Steffes MW, Striker GE, Viberti GC: Prevention of diabetic renal disease with special reference to microalbuminuria. Lancet 1995;346:10801084.

-94 Forman JP, Brenner BM: "Hypertension" and "microalbuminuria": the bell tolls for thee. Kidney Int 2006;69:22-28.

$\$ 95$ Remuzzi G, Macia M, Ruggenenti P: Prevention and treatment of diabetic renal disease in type 2 diabetes: the BENEDICT study. J Am Soc Nephrol 2006;17:S90-97.

96 Kalaitzidis R, Bakris G: Pathogenesis and treatment of microalbuminuria in patients with diabetes: the road ahead. J Clin Hypertens (Greenwich) 2009;11:636-643.

$\$ 97$ Alfie J, Aparicio LS, Waisman GD: Current strategies to achieve further cardiac and renal protection through enhanced renin-angiotensin-aldosterone system inhibition. Rev Recent Clin Trials 2011;6:134-146.

98 Sharkovska Y, Alter M, Reichetzeder C, Tsuprykov O, Klein T, Hocher B: Linagliptin Offers a New Therapeutic Approach for ARB-Resistant Diabetic Nephropathy; in: 72nd Sci Sess of the American Diabetes Association (ADA), 2012, p 986-P.

-99 Hattori S: Sitagliptin reduces albuminuria in patients with type 2 diabetes. Endocr J 2011;58:69-73.

100 Groop P, Cooper M, Perkovic V, Emser A, von Eynatten M, Woerle H: Linagliptin Lowers Albuminuria on Top of Recommended Standard Treatment for Diabetic Nephropathy; in: 72nd Sci Sess of the American Diabetes Association (ADA), 2012, p 953-P.

101 Bethel M, Green J, Califf R, Holman R: Rationale and design of the trial evaluating cardiovascular outcomes with sitagliptin (TECOS). Diabetes 2009;58:2152.

102 Schweizer A, Dejager S, Foley JE, Couturier A, Ligueros-Saylan M, Kothny W: Assessing the cardiocerebrovascular safety of vildagliptin: meta-analysis of adjudicated events from a large Phase III type 2 diabetes population. Diabetes Obes Metab 2010;12:485-494.

-103 Frederich R, Alexander JH, Fiedorek FT, Donovan M, Berglind N, Harris S, Chen R, Wolf R, Mahaffey KW: A systematic assessment of cardiovascular outcomes in the saxagliptin drug development program for type 2 diabetes. Postgrad Med 2010;122:16-27.

104 Anon.: ClinicalTrials.gov - The Vascular Effects of Vildagliptin in Insulin Resistant Individuals

105 Anon.: CAROLINA - Cardiovascular Outcome Study of Linagliptin Versus Glimepiride in Patients With Type 2 Diabetes

106 Anon.: Cardiovascular Outcomes Study of Alogliptin in Subjects With Type 2 Diabetes and Acute Coronary Syndrome

107 Chaykovska L, Tsuprykov 0, Hocher B: Biomarkers for the prediction of mortality and morbidity in patients with renal replacement therapy. Clin Lab 2011;57:455-467.

-108 Hocher B, Ziebig R, Altermann C, Krause R, Asmus G, Richter C-M, Slowinski T, Sinha P, Neumayer H$\mathrm{H}$ : Different impact of biomarkers as mortality predictors among diabetic and nondiabetic patients undergoing hemodialysis. J Am Soc Nephrol 2003;14:2329-2337.

109 Johansen OE, Neubacher D, von Eynatten M, Patel S, Woerle H-J: Cardiovascular safety with linagliptin in patients with type 2 diabetes mellitus: a pre-specified, prospective, and adjudicated meta-analysis of a phase 3 programme. Cardiovasc Diabetol 2012;11:3.

-110 Williams-Herman D, Engel SS, Round E, Johnson J, Golm GT, Guo H, Musser BJ, Davies MJ, Kaufman KD, Goldstein BJ: Safety and tolerability of sitagliptin in clinical studies: a pooled analysis of data from 10,246 patients with type 2 diabetes. BMC Endocr Disord 2010;10:7.

111 White W, Gorelick P, Fleck P, Smith N, Wilson C, Pratley R: Cardiovascular Events in Patients Receiving Alogliptin: A Pooled Analysis of Randomized Clinical Trials; in: 70th Sci Sess of the American Diabetes Association (ADA), 2012, p 391-P.

112 Vickers SP, Cheetham SC, Birmingham GD, Rowley HL, Headland KR, Dickinson K, Grempler R, Hocher B, Mark M, Klein T: Effects of the DPP-4 Inhibitor, Linagliptin, in Diet-Induced Obese Rats: A Comparison in

Naive and Exenatide-Treated Animals. Clin Lab 2012;58:787-799. 